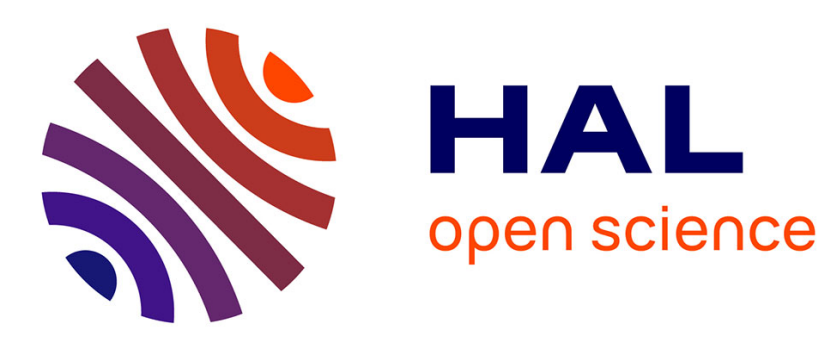

\title{
Planation surfaces as a record of mantle dynamics: The case example of Africa
}

François Guillocheau, Brendan Simon, Guillaume Baby, Paul Bessin, Cécile Robin, Olivier Dauteuil

\section{- To cite this version:}

François Guillocheau, Brendan Simon, Guillaume Baby, Paul Bessin, Cécile Robin, et al.. Planation surfaces as a record of mantle dynamics: The case example of Africa. Gondwana Research, 2018, 53, pp.82-98. 10.1016/j.gr.2017.05.015 . insu-01534695

\section{HAL Id: insu-01534695 https://hal-insu.archives-ouvertes.fr/insu-01534695}

Submitted on 8 Jun 2017

HAL is a multi-disciplinary open access archive for the deposit and dissemination of scientific research documents, whether they are published or not. The documents may come from teaching and research institutions in France or abroad, or from public or private research centers.
L'archive ouverte pluridisciplinaire HAL, est destinée au dépôt et à la diffusion de documents scientifiques de niveau recherche, publiés ou non, émanant des établissements d'enseignement et de recherche français ou étrangers, des laboratoires publics ou privés. 


\section{Accepted Manuscript}

Planation surfaces as a record of mantle dynamics: The case example of Africa

François Guillocheau, Brendan Simon, Guillaume Baby, Paul Bessin, Cécile Robin, Olivier Dauteuil

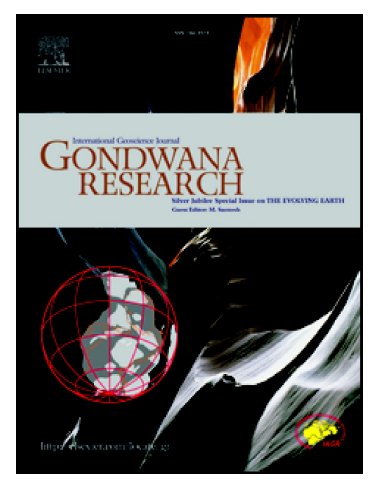

PII:

S1342-937X(17)30249-6

DOI:

doi: 10.1016/j.gr.2017.05.015

Reference:

GR 1819

To appear in:

Received date: $\quad 4$ June 2016

Revised date: $\quad 15$ May 2017

Accepted date: $\quad 18$ May 2017

Please cite this article as: François Guillocheau, Brendan Simon, Guillaume Baby, Paul Bessin, Cécile Robin, Olivier Dauteuil , Planation surfaces as a record of mantle dynamics: The case example of Africa, (2017), doi: 10.1016/j.gr.2017.05.015

This is a PDF file of an unedited manuscript that has been accepted for publication. As a service to our customers we are providing this early version of the manuscript. The manuscript will undergo copyediting, typesetting, and review of the resulting proof before it is published in its final form. Please note that during the production process errors may be discovered which could affect the content, and all legal disclaimers that apply to the journal pertain. 


\section{Planation surfaces as a record of mantle dynamics: the case example of Africa}

François Guillocheau ${ }^{\mathrm{a}}$, Brendan Simon, Guillaume Babya, Paul Bessina, , Cécile Robinn, Olivier Dauteuila

${ }^{\mathrm{a} G e ́ o s c i e n c e s-R e n n e s, ~ U M R} 1618$ Université de Rennes 1 - CNRS, OSUR, Université de Rennes 1, 35042 Rennes cedex, France

bUniversité du Maine, Avenue Olivier Messiaen, 72085 Le Mans cedex 9, France

Corresponding author: François Guillocheau, françois.guillocheau@univ-rennes1.fr

ABSTRACT

There are two types of emerged relief on the Earth: high elevation areas (mountain belts and rift shoulders) in active tectonic settings and low elevation domains (anorogenic plateaus and plains) characteristic of the interior of the continents i.e. $70 \%$ of the Earth emerged relief. Both plateaus and plains are characterized by large erosional surfaces, called planation surfaces that display undulations with middle (several tens of kilometres) to very long (several thousands of kilometres) wavelengths, i.e. characteristic of lithospheric and mantle deformations respectively.

Our objective is here (1) to present a new method of characterization of the very long and long wavelength deformations using planation surfaces with an application to 
Central Africa and (2) to reconstruct the growth of the very long wavelength relief since $40 \mathrm{Ma}$, as a record of past mantle dynamics below Central Africa.

(i) The African relief results from two major types of planation surfaces, etchplains (weathering surfaces by laterites) and pediplains/pediments. These planation surfaces are stepped along plateaus with different elevations. This stepping of landforms records a local base level fall due to a local tectonic uplift.

(ii) Central Africa is an extensive etchplain-type weathering surface - called the African Surface - from the uppermost Cretaceous (70 Ma) to the Middle Eocene (45 Ma) with a paroxysm around the Early Eocene Climatic Optimum. Restoration of this surface in Central Africa suggests very low-elevation planation surfaces adjusted to the Atlantic Ocean and Indian Ocean with a divide located around the present-day eastern branch of the East African Rift.

(iii) The present-day topography of Central Africa is younger than 40-30 Ma and records very long wavelength deformations $(1000-2000 \mathrm{~km})$ with (1) the growth of the Cameroon Dome and East African Dome since $34 \mathrm{Ma},(2)$ the Angola Mountains since 1512 Ma increasing up to Pleistocene times and (3) the uplift of the low-elevation (300 m) Congo Basin since 10-3 Ma. Some long wavelength deformations (several $100 \mathrm{~km}$ ) also occurred with (1) the low-elevation Central African Rise since $34 \mathrm{Ma}$ and (2) the Atlantic Bulge since 20-16 Ma. These very long wavelength deformations record mantle dynamics, with a sharp increase of mantle upwelling around $34 \mathrm{Ma}$ and an increase of the wavelength of the deformation and then of mantle convection around 10-3 Ma.

Keywords: Planation surfaces, Mantle dynamics, Weathering, Africa, East African Rift 
The emerged relief of the Earth is composed of three main types of forms, besides large volcanoes: (1) mountain belts and associated orogenic plateaus, (2) rift shoulders and (3) anorogenic plateaus and plains. These latter types, plateaus and plains, are the specific landforms for most of the interior of the continents (Africa, Australia, eastern parts of both South and North America, Eurasia north of the Alpine mountain belts, southern and central India). They represent approximately $70 \%$ of the emerged relief on the Earth. Both plateaus and plains are characterized by large subplanar surfaces. For plains, these surfaces can be depositional (subsiding domain), by-passing (no subsidence, no uplift) or erosional (uplift). For plateaus, they are mostly erosional.

These erosional surfaces are called planation surfaces (Migon, 2004a) or palaeosurfaces (Widdowson, 1997). They correspond (Brown, 1968; Migon, 2004b) to nearly flat erosional surfaces, truncating a heterogeneous mosaic of hard rocks, with no or little discontinuous (several metres-thick) sedimentary cover. Hard rocks can be basement rocks (metamorphic and plutonic rocks), volcanic rocks as well as lithified sedimentary rocks of recent (with respect to the age of the surface) interior basins or margins. These surfaces can be subtabular or slightly inclined (reaching several degrees locally), displaying undulations with middle (several tens of kilometres) to very long (several thousands of kilometres) wavelengths. Their surface area ranges from several $\mathrm{km}^{2}$ to $10^{5} \mathrm{~km}^{2}$. The underlying hard rocks can be fresh or weathered. There are at least six types of planation surfaces (Migon, 2004a): peneplains (fluvial erosion by slope downwearing, Davis, 1899 and Migon, 2004b and Ebert, 2009 for discussions), pediplains and pediments (backwearing of escarpments, King, 1953 and Dohrenwendt and Parsons, 2009 for a review), etchplains (weathering surfaces, Wayland, 1933; Büdel, 
1957; Thomas 1989ab), wave-cut platforms (marine terraces, Ramsay, 1846; Fairbridge, 1952), cryoplanation surfaces (Thorn, 2004) and glacial surfaces.

Planation surfaces were at the root of the original debates in geomorphology (Orme, 2013) as the end-member of the erosion cycle (or geographical cycle) defined by W.M. Davis (1899). Research on these landforms was very active until the 1970s. Unfortunately simplistic assumptions (e.g. King, 1962) regarding their geometry ("all the surfaces are flat"), their dating ("the age of a surface is a function of its elevation"), their elevation at the time of formation ("all the surfaces formed at sea level") combined with the progress made on understanding lithosphere deformation with the birth of plate tectonics and the evolution of geomorphology toward a more physical science, have resulted in the studies on planation surfaces and the associated low elevation relief being relegated to the background.

Planation surfaces, today preserved as plateaus, are assumed to have resulted from tectonic uplifts (e.g. Lidmar-Bergström et al., 2013; Japsen et al., 2016), for which even the kinematics and causes of these uplifts have been (are) debated (Gilchrist and Summerfield, 1990; Braun et al., 2014; Colli et al., 2014). They are related to subtle low amplitude low inclination tiltings, called epeirogenic movements since Gilbert (1890). At the scale of low-elevation continental interiors, these surfaces record undulations (Lidmar-Bergström, 1996; Peulvast and Sales, 2004; Chardon et al., 2006) with long (several $100 \mathrm{~km}$ ) to very long (several $1000 \mathrm{~km}$ ) wavelengths with an amplitude of several tens to several hundreds of kilometres, respectively. These wavelengths correspond to lithospheric deformations via buckling or boudinage (long wavelength several $100 \mathrm{~km}$, Cloetingh and Burov, 2011; Burov, 2011) or mantle dynamics (very long wavelength - several 1000 km, e.g. Braun, 2010; Burov and Gerya, 2014; Colli et al., 2016). Such very long wavelength deformations have already been characterized at the 
scale of a continent, Australia, using the stratigraphic record (e.g. Heine et al., 2010) and were related to dynamic topography effects.

Our first objective is here to show that these planation surfaces are major geomorphological markers of the earth surface deformation in response to lithosphere and/or mantle dynamics according to the wavelength of the deformation (see above). This new method will be applied to the case example of Central Africa. The second objective is to focus on the growth of very long wavelength (several $1000 \mathrm{~km}$ ) landforms (larges plateaus), record of mantle-induced surface deformation, to reconstruct past mantle dynamic below Central Africa since 40 Ma. This study is based on a review of the different types of planation surfaces encountered in Africa.

The African topography (Fig. 1) has a dual characteristic: (1) it displays a unique bimodal distribution (Harrison et al., 1993) and (2) it shows a specific "basin and swell" pattern (Holmes, 1944) with a wavelength between swells of 1000 to $2000 \mathrm{~km}$. The elevation distribution of Africa has two modes (Fig. 1b): a first one around 300-400 m corresponding to the mean elevation of the Sahara (northern Africa) and the Congo Basin, and a second one around 900-1100 m due to the Southern African (or Kalahari) Plateau, the East African and Ethiopian domes and the Hoggar, Aïr, Tibesti and Darfur highs in the Sahara. The cause of the "basin and swell" pattern in the African topography has been discussed by several authors and related to mantle dynamics (e.g. Burke and Wilson, 1972; McKenzie and Weiss, 1975; England and Houseman, 1984). Burke (Burke, 1996; Burke et al., 2003) claimed that it was an Oligocene topography due to the Ethiopian Plume. These same authors (Burke, 1996; Burke and Gunnell, 2008) emphasized the relationships between mantle deformations, swell formations and a 
weathering surface called the African Surface. The analysis of this surface is the main goal of our study, which focuses on Central Africa.

\section{Planation surfaces of Africa: etchplains and pediplains.}

There are two main types of planation surfaces in Africa: etchplains and pediplains/pediments.

\subsection{Etchplains (Fig. 2)}

Characteristics. Etchplains are weathering surfaces due to the growth of lateritic profiles requiring hot and very humid conditions in a tropical climatic setting (Wayland, 1933; Büdel, 1982; Thomas, 1994).

There are two types of these etchplains (Fig. 2), mantled and stripped (Migon, 2004c). Mantled etchplains preserve a complete lateritic profile, with duricrusts on top and saprolites underneath (kaolinites and insoluble elements such as quartz, Tardy, 1997) with a thickness up to $100 \mathrm{~m}$ to the weathering front (also called etch-surface). The duricrust can be made up of iron (iron duricrusts) or bauxites. In plan view (Fig. 2a), mantled etchplains display a characteristic pattern of low duricrust hummocks (around one kilometre wide with an amplitude of 10-20 m), called Bowal (plural Bowé, de Chetelat, 1938; Buckle, 1978 - a vernacular word from NW Africa borrowed by the soil geologists). Stripped etchplains are mantled etchplains that are eroded by alluvial processes. The erosion of the weathering profile (Migon, 2004c) can be partial (some of the saprolite remains) - defining a partly stripped etchplain - or mostly full (complete removal of the laterite) up to the weathering front. Due to the irregular geometry of the 
weathering front of the laterites, the stripping of the saprolite leaves a residual relief corresponding to the areas with thin weathering profiles (Fig. 2b). They are called inselbergs (or tors and bonhardts according to their either small or large size - e.g. Ollier, 1960; Twidale and Bourne, 1978).

In Africa, these surfaces are mainly preserved on the top of high plateaus (mantled etchplains) or as inselberg fields. In these two cases (Mabbutt, 1966; Twidale and Bourne, 2013a), they are remnants of larger etchplains, today dissected by younger landforms (pediplains/pediments and/or incised valleys). They can also shape lower elevation planation surfaces, and even some plains.

They are widespread in Africa, from Morocco in northern Africa (inselbergs fields in the eastern Anti-Atlas, Riser, 1975) to South Africa (laterites on the top of the Southern African Plateau - Maud, 1965 - or close to sea level in the Western Cape Province Marker et al., 2002). Today, they extend far beyond the tropical belt, in semi-arid to arid domains (e.g. Hoggar in the Sahara - Bordet, 1951 - or southward of the Namib Desert in the Sperrgebiet area of Namibia - Pickford, 2015). The best examples of preserved etchplains are in Guinea (Guinea Rise) and southern Mali (Mandingues Plateau Chardon et al., 2006). They are also major features of the relief in Cameroon, Central African Republic, the northern Congo Basin and Uganda.

Discussion. The mode of formation of these surfaces is still poorly understood and debated (Bremer, 1993; Thomas, 1994, Migon, 2004c). Many studies have been performed on the vertical growth of lateritic profiles (see Tardy, 1997). Few studies (e.g. Strudley, 2006) have tried to couple erosion weathering processes with the geomorphology and base level fluctuations in order to understand their lateral evolution (Braun et al., 2016). 
Most of these African etchplains, even those that were shaped some tens of millions years ago (Beauvais et al., 2008), are still active with rates that are lower than at their period of formation. Cosmogenic studies in Cameroon (Braucher et al., 2000) indicate a vertical rate of erosion of $2 \mathrm{~m} / \mathrm{Ma}$ for mantled etchplains under the present-day hot very humid conditions. For stripped etchplains and under arid to semi-arid conditions, the present-day erosion rate of the inselbergs is between 1 and $2 \mathrm{~m} / \mathrm{Ma}$ (cosmogenic isotopes on the inselbergs of Namibia, Matmon et al., 2013).

\subsection{Pediments/Pediplains: the pediment system concept (Fig. 3)}

Characteristics. Pediments are nearly flat erosional surfaces, which are bounded upslope by scarps connecting with upstanding landforms (Tator, 1952, 1953; Whitaker, 1979; White, 2004; Dohrenwendt and Parsons, 2009). The size of this landform is highly variable (Fig. 3a); the flat erosional surface can extend from 1-10 km (called pediments) up to hundreds of kilometres long (called pediplains).

The nearly flat surfaces (Fig. 3) have a rectilinear to slightly concave profile with slope angles for the African examples varying from $1^{\circ}\left(1.75 \%\right.$ - small pediments) to up to $10^{-}$ 3\% (large pediplains). This surface is free of sediments, except for discontinuous thin layers (approximately several metres thick) of alluvial or aeolian deposits. The underlying hard rocks can be fresh or weathered. In latter case, this may be a stripped lateritic weathering profile (with remnants of kaolinitized rocks in the saprolite, e.g. a stripped etchplain) or more or less rocks covered by an iron duricrust coating alluvial deposits.

The upstream scarps (Fig. 3) have a mean steepness varying from $1^{\circ}$ to $30^{\circ}$, sometimes ending upslope with a subvertical cliff. In some cases, the transition with the upstanding 
landform may be more progressive, with a pediment merging to the above landform. In 3D view, scarps can be continuous smooth slopes or incised by valleys. In this case, the rivers incising the valleys have adjusted to the flat surface of the pediments which constitutes a local base level for these rivers.

In plan view (Fig. $3 \mathrm{~b}$ ) and with respect to the regional slope, the geometry of the pediment may be (1) bounded by a nearly straight to slightly sinuous escarpment at a right angle from the slope with no or few upslope incised valleys, (2) bounded by a highly dissected scarp with numerous upscarp long (several tens of kilometres to 100 $\mathrm{km}$ ) incised rivers or (3) organized into large flat valleys (width: 50-200 km, length: $100-500 \mathrm{~km}$ ) elongated in the slope, called pedivalleys.

We defined (Guillocheau et al., 2015) the concept of a pediment system (Fig. 3c) which summarizes the relationships between pediplains, pediments and incised valleys. A downslope pediplain passes upstream to pediments displaying more or less pronounced re-entrants in the upslope landform (up to pedivalleys) and then upscarp to incised valleys. Some remnants of the upstanding landforms are preserved as inselbergs in the pediments or pediplain. The pediplain is the local base level of both the pediments and incised valleys.

Discussion. Two modes of pediment formation (see White, 2004 and Dohrenwendt and Parsons, 2009 for discussions) have been proposed (1) by mechanical erosion and (2) by combined chemical and mechanical erosional processes. The idea behind this is that they are two types of pediments: the first one is shaped under semi-arid conditions (mechanical erosion) and the second one under hot very humid conditions (mixed). The nature of the processes responsible for mechanical erosion is discussed as well: large 
pediment-scale sheet floods or highly avulsionary anastomosed rivers (multiple lateral shifts of anabranched rivers).

In Africa, most of the pediments show evidence of chemical weathering processes as suggested by the occurrence of remains of either weathered rocks on the nearly flat surface or inselbergs. This supports a mixed origin through chemical-assisted mechanical erosion for these pediments in agreement with the models proposed by Twidale and Bourne (2013b) following the pioneering works of Büdel (1957) and Thomas (1989ab).

As etchplains discussed before, pediments and pediplains are still today active landforms. However, the rate of the present-day scarp retreat is quite low, between 1 and $10 \mathrm{~m} / \mathrm{Ma}$ (cosmogenic studies in South Africa and Namibia, e.g. Cockburn et al., 2000; Decker et al., 2013).

Some pediments have preserved thin layers of alluvial sediments and/or show evidence of dentritic alluvial networks which have already been extensively studied in semi-arid environments (e.g. Tooth et al., 2007). The main question is the age relationships between the alluvial sediments and the pediments: are they contemporaneous or younger alluvial systems superimposed onto fossil pediments?

\subsection{Burial and exhumed planation surfaces}

Some planation surfaces can be old planation surfaces that where buried due to lithosphere subsidence and then covered by sediments. The depth of burial can range from few hundreds to few thousands of metres. A good illustration in Africa is provided by the uppermost Devonian to Early Permian Gondwana glaciation covering most of Central and South Africa (Dwyka glacial deposits of the base Karoo basins, Catuneanu et 
al., 2005). This is a buried surface (at least covered by the Karoo sediments of Late Carboniferous to Early Jurassic age) that was later exhumed by different tectonic uplifts during Mesozoic and Cenozoic times. The best examples are preserved in the southern Angolan Plateau and Mountains, where the present-day planation surface is mostly inherited from this glacial period (e.g. de Wit, 2007).

\section{Stepped pediment-type planation surfaces: a record of uplift}

\subsection{Principles (Fig. 5, 6)}

African plateaus are characterized by several stepped planation surfaces, which have the same pattern everywhere in Africa (Fig. 5a). From the top to the base of the plateau, one or two etchplains pass downward to several stepped pediments and pediplains.

The stepping of pediment-type planation surfaces can be interpreted into two different ways (Fig. 5b): (1) a synchronous retreat of the scarps in all the stepped pediments after an initial uplift of the plateau, (2) a successive growth of the pediments in response to an uplift, where the lowest pediment is the youngest. For the latter case, the uplift can be steady with several variations of the climate regime (precipitation) that control changes in the erosion pattern and then in the growth of the pediments (case of the Fig. 5b Beauvais et al., 2013) or transient with a discontinuous uplift.

In the case of African plateaus, four arguments support the second scenario, i.e. landform stepping is controlled by a tectonic uplift (Fig. 6).

- Each pediment/pediplain surface is a local base level. As mentioned previously, pediments are organized as pediment systems in which incised upstream valleys are 
adjusted to the nearly flat surface of the pediments and pediplains, which constitutes the local base level of these incised rivers.

When two pediment systems are stepped (Fig. 6a), the upstream part of the incised valley network for the lowest pediment system does not reach the downstream part of the incised valleys in the highest pediment system. Modern rivers passing from the highest to lowest incised valley networks by-pass over the nearly flat surface of the highest pediments. The absence of connectivity between the two incised valley networks (the highest and the lowest) indicate (1) that the highest network of valleys was first incised by rivers in base level connection with the highest pediments and (2) that the second network is younger and shaped at time of the growth of the lowest pediment system. It implies that the lowest and highest incised valleys are not contemporaneous: the highest one is older and a kind of "fossil" landscape, even though both chemical and mechanical erosion are later active but at lower rates. This confirms that both pediments, the highest and the lowest, are local base levels for the incised upstream river network. Consequently, the stepping between the highest and lowest pediment systems records a base level fall.

- The degradation of planation surfaces via river incision decreases from the top to the base of the plateaus (Fig. 6a). Planation surfaces can be characterized by the rate of preservation/degradation through alluvial processes on the surface, ranging from a fully preserved surface (no degradation) to highly dissected surfaces where the surface is only preserved as flat-topped stubs (high degradation). For all the stepped landforms, the highest planation surfaces show the highest rate of degradation and the lowest ones are almost fully preserved. This indicates a longer degradation by the rivers of the highest planation surfaces and a shorter one for the lowest 
pediments, suggesting that the highest ones due to their longer exposure to alluvial erosion, are older than the lowest ones.

- Even though few datings are available, the age of the planation surfaces are older on top and younger at the base of the plateaus. In western Africa (Burkina Faso, Mali), the dated old weathering profiles are located on the highest surfaces (Bauxitic surface=African Surface, Beauvais et al., 2008) and the youngest on the lowest surface (Higher Glacis, Vasconcelos et al., 1994).

- In some cases, the flat surfaces of successive pediments are tilted. All the recent pediplains of Africa have the same angle on their downslope part, ranging from $10^{-2}$ to $10^{-3} \%$. In some cases and for the same location along the pediment/pediplain profile with respect to the scarp, the highest planation surfaces have steeper slopes than the lowest surfaces. This suggests an uplift via doming of the plateau.

All these facts suggest that stepped pediments record base level falls, where the highest pediments are the oldest and the lowest ones the youngest. Base level variations record either tectonic vertical movements or sea or lake level variations if the pediments are connected to the sea or to lakes. Schumm (1993) studied the effect of sea level fluctuations on very low slope river systems and showed the buffer effect of this very low slope with respect to the base level fluctuations and the absence of any stratigraphic record. The implication here for pediplains and etchplains with very low slopes is that they are not able to record far field base level fluctuations such as sea or lake levels variations. They can only record local base level changes, i.e. lithosphere/mantle deformation.

The vertical displacement between two successive flat surfaces of pediments provides a proxy for the measurement of the surface uplift. 


\subsection{Application to the Congolese side of the East African Plateau (Fig. 7)}

In eastern Congo (RDC - North Kivu Province), the transition between the Congo Basin and East African Dome (see Fig. 1 for general location) shows good evidence of stepped planation surfaces. Four generations of major regional stepped planation surfaces (Fig. 7) were defined (Guillocheau et al., 2015), from highest to lowest: (1) the highly degraded etchplain u1, (2) the degraded etchplain/pediplain u2, (3) the duricrusted pediplain $\mathrm{l}$ and (4) the well-preserved pediment $\mathrm{x}$ (with two inset ones $\mathrm{x} 1$ and $\mathrm{x} 2$ ). Pediment $\mathrm{x}$ is connected to the local base level of the Congo Basin. This area (Fig. 7a) displays two different types of pediment geometry, a pediment with sinuous scarps with few incised rivers to the north and pediment valleys connecting upscarps to long incised valleys.

The evidence for uplift is as follows: (1) incised valleys adjusted to the flat surface of pediplain l (degrading u2) but disconnected from the incised valleys adjusted to pediment $x$ (arrows on Fig. 7a), indicating a downward migration of the base level from $\mathrm{u} 2$ to $\mathrm{x}$; (2) increasing degradation by rivers from pediment $\mathrm{x}$ to etchplain/pediplain $\mathrm{u} 2$ (circle on Fig. 7b), indicating an older age for $\mathrm{u} 2$ and a younger one for $\mathrm{x}$ and (3) tilting (Fig. $7 \mathrm{~b})$ of the flat surface of pediplain u2 with respect to pediment $\mathrm{x}(0.25-0.5 \%$ vs. $\left.6.10^{-2} \%\right)$.

The successive nearly flat pediments/pediplains - irrespective of the amount of the tilting - merge westward to a single line that more or less corresponds to the presentday Congo River (eastern limit of the Congo Basin). This suggests the growth of a dome from the same perennial base level, the Congo Basin. 


\section{The African Surface - a long-lasting etchplain (70-40 Ma) at Africa-scale - nature, age, mapping}

\subsection{Characteristics}

As already mentioned, most of the highest plateaus in Africa correspond to remnants of mantled (sometimes with bauxites) or stripped (inselberg fields) etchplains. Nevertheless, remnants of etchplains are also preserved at lower elevation on low altitude plateaus. In 3D view and at the scale of hundreds of kilometres, these low and high elevation residual etchplains are in continuity and delineate large undulating planation surfaces dissected by younger pediments or pediplains and incised valleys.

The occurrence of such highly elevated duricrusted planation surfaces has already been observed by soil geologists and geomorphologists (for German-speaking authors: Jessen, 1936; for French-speaking authors: e.g. Cahen, 1954; Michel, 1973; Grandin, 1976; Millot, 1981; for English-speaking authors: e.g. King, 1949; Pugh, 1954, Ollier, 1960, McFarlane, 1976). Parts of this etchplain were called the African Surface by King (1962) on elevation criterions. This name became very popular and was extensively used in the absence of a clear definition (nature, age...) of this surface. Later on, Burke and Gunnell (2008) recognized this deformed surface over all of Africa using more geologically significant criteria than King.

Two questions now have to be addressed, (1) the reality of an Africa-scale etchplain and its existence as the same physical surface that was shaped during the same time-interval and (2) the age of its formation.

\subsection{Mapping of the oldest etchplains in Central Africa}


The oldest etchplains in Central Africa were mapped in two steps. (1) For each main morphological unit of Africa (e.g. Cameroon Highlands or Angolan Plateau), a chronological study of the stepped planation surfaces was performed to ensure that, from one unit to another one, the top etchplains are really at the same relative chronological position. (2) A map was made of these undulating etchplains based on their physical continuity at the scale of each morphological unit and in between these units. These studies were based on the analysis of Digital Elevation Models (SRTM - see Bessin et al., 2015 for a presentation of this mapping technique) which were verified by field studies and/or numerous published local observations on landforms and weatherings.

At the scale of the studied area (Central Africa), the studied etchplains are in the same relative chronological location from the Cameroon Highlands to the East African Dome and Angola Plateaus (Guillocheau et al., 2015; Simon, 2015). Nevertheless this etchplain is not a single surface; in fact, two or three inset etchplains are stacked on top of the plateaus, sometimes located below an older highly degraded unweathered relief (mainly made up of quartzites).

\subsection{Age of the oldest etchplain (Fig. 8): redefinition of the African Surface}

The age of this oldest etchplain (and its associated weathering profiles) was determined based on (1) the dating of the laterite profiles, (2) the interfingering or reworking of the laterites in the sedimentary record of the surrounding sedimentary basins and (3) the geometrical relationships with dated magmatic rocks. Because the weathering of an 
etchplain requires hot very humid conditions, ages were tested using paleoclimate reconstructions (primarily paleoprecipitation).

- Dating of the laterites: Two types of dating are available in Africa (Fig. 8) based on ${ }^{39} \mathrm{Ar}-{ }^{40} \mathrm{Ar}$ dating of different minerals formed at the time of the weathering (cryptomelane, jarosite, etc.) and on palaeomagnetism based on the magnetic signal preserved by iron-rich minerals syngenetic to the weathering.

- Interfingering and reworking in sediments: Lateritic profiles can be preserved in the sedimentary record during a major relative base level (sea or lake) fall and of the consecutive emersion. This is quite unusual (Iullemmeden Basin - Niger; southern margin of Namibia). The common occurrence is the precipitation of iron coming from the continent into marine or lacustrine environments as iron ooids (Van Houten, 1992) or the transformation in wetlands of kaolinite coming from saprolite into smectites (attapulgite, Chamley, 1989). This second technique implies a low transportation of clays to ensure that smectites are not later reworked in younger sediments.

- Geometrical relationships with the magmatism: In places with continuous magmatic activity (e.g. Cameroon Volcanic Line, Virunga-Kivu Province, Hoggar, Aïr, etc. Fig. 1), planation surfaces can cut across dated plutons or lavas and be later covered by younger lavas, providing a time-range for the formation of the etchplains or pediments.

- Paleoprecipitation reconstructions: This approach is mainly based on palaeobotanical compilations (Fig. 8) with the assumption that Cenozoic floras have similar climatic settings as the modern equivalents. Two types of data are used: pollens and spores, and preserved pieces of plants (woods and leaves). Two points limit these reconstructions. (1) Some Early Cenozoic plants (66-34 Ma - Paleocene- 
Eocene) have no present-day equivalents and then cannot be used for reconstructions. (2) The definition of fossil pollen and spores is based on a double taxonomic nomenclature, one is established on an equivalence between the spores/pollen and the plants and the other one is specific to the palynology - only data using the first nomenclature can be used. The paleoprecipitation characterization is quite approximate and ranges from very humid, humid, semi-arid to arid settings.

The age of this oldest etchplain (Fig. 8) ranges from at least 70 to $40 \mathrm{Ma}$ (Maastrichtian to lowermost Late Eocene). This confirms a long-lasting polygenic surface as expected by the occurrence of two or three inset etchplains (3.2). Most of the ages come from the area between North and Central Africa. Few ages are available in southern Africa (only southern Namibia).

The compilation of the weathering ages suggests four main periods of weathering on the scale of Africa since 145 Ma (base Cretaceous): Albian-Cenomanian (113-94 Ma), Coniacian-Santonian (89-84 Ma), Maastrichtian to Bartonian? (72-40 Ma) and Burdigalian to Serravallian (20-12 Ma). The Maastrichtian-Bartonian? period can probably be subdivided into two subperiods of higher weathering rates during Maastrichtian (72-66 Ma) and Thanetian-Bartonian? (60-40 Ma) times. The age of the African Surface is in agreement with the Thanetian-Bartonian? weathering subperiod which fits with the climatic optimum of the Early Eocene (EECO, Zachos et al., 2001). This also implies a weathering reactivation for the etchplains of the African Surface during Early and Middle Miocene times (20-12 Ma) as previously expected.

We here defined the African Surface as an Africa-scale long-lasting etchplain ranging from at least $70 \mathrm{Ma}$ to $40 \mathrm{Ma}$, later deformed and now located at different elevations. 
Compared to the works of King $(1949,1962)$, based on the assumption that all the weathering surfaces are at the same elevation, the surface mapped here comprises most of its African Surface, but also include most of its Post-Gondwana and Gondwana Surfaces. Nevertheless, we agree that some older relict relief exist in Central Africa (see 4.2) but their geographical distribution is less than expected by King.

\section{Deformation of the African Surface in Central Africa as a consequence of very long wavelength deformations}

\subsection{The present-day 3D geometry of the African Surface in Central Africa (Fig. 9)}

The studied area extends (Fig. 1), from north to south, from the plains of southern Chad and Sudan (Cretaceous to Paleogene rifts) to the northern part of the southern African (Kalahari) Plateau (Angolan Plateau and Zambia highlands) and, from west to east, from the Atlantic Ocean to the Indian Ocean.

The mapped geological elements are (1) remnants of etchplains (mantled or stripped) on plateaus that have been validated as being in the same chronological position of the landform (see above), (2) weathering profiles in plains located over sediments older than the Paleocene-Eocene and corresponding to the local base level of younger stepped pediplains/pediments (Congo Basin, Guillocheau et al., 2015) and (3) for the subsiding areas (sedimentary basins), sediments (continental or marine) deposited during this time interval and mainly during Early to Middle Eocene times (passive margins of the Atlantic Ocean and Indian Ocean, Cretaceous to Paleogene rifts in Chad, Sudan and Kenya - the Termit, Logone, Bongor, Doba, Doseo, Salamat, Abu Gabra-Muglad, Melut, Bara, Kosti, Blue Nile and Anza rifts - Guiraud and Maurin, 1992 - Fig.1). 
In the case of the stripped etchplains, the African Surface was delineated on top of the highest inselbergs, underestimating its true elevation which has to be higher on top of the stripped weathering surface; it is unfortunately impossible to determine this thickness.

The African Surface (Fig. 9) merges with sediments from the Atlantic and Indian Margins, both onshore and offshore, with respect to the present-day shoreline (transition to depositional subsiding domains). It is more or less at the level of the present-day topography in the Congo Basin i.e. around $300 \mathrm{~m}$ and is predominantly above in the surrounding relief of the Congo Basin.

The African Surface displays two types of forms: large domes with sizes from 1000 to $1500 \mathrm{~km}$ and an heights from 2000 to $2500 \mathrm{~m}$ by taking the present-day Congo Basin flat as the level of reference and bulges, elongated forms with a width of 300 to $800 \mathrm{~km}$ and an heights of 200 to $1000 \mathrm{~m}$. Four large domes were recognized, from largest to smallest, the East African, Ethiopian, Cameroon and Angola Domes. These domes may be linked by elongated bulges, e.g. the Central African Atlantic Swell and the subdued Central African Rise, or bounded by depressions, e.g. the Turkana Gap. The topography of the East African Dome can be broken down into two wavelengths, a very long one corresponding to the dome itself and a long one with two bulges corresponding to each branch of the East African Rift.

All these domes, bulges and rises show evidence of stepped planation surfaces with the above criteria that are indicative of tectonic uplifts (Guillocheau et al., 2015; Simon, 2015). 
The different etchplains and pediments/pediplains that have been shaped since the formation of the African Surface, were drawn along a W-E topographic profile from northern Gabon to southern Kenya through Uganda (Fig. 10) based on the works of Guillocheau et al. (2015) and Simon (2015). Six main generations of landforms were mapped using the nomenclature of Guillocheau et al. (2015): from oldest to youngest, (1) remnant degraded "old" relief, (2) the African Surface, (3) an intermediate etchplain/pediplain (u2), (4) a pediplain (1), (5) a major pediment (x), and (6) "recent" pediments ( $y$ and $z$ ). Landforms (1) to (3) were recognized all along the profile. Because of the initiation of the rifts in the eastern branch of East African Rift - and then the creation of local base levels - after u2, two specific successive landforms were identified only along the East African Dome: (1) major pediplains and (2) incised rivers. Based on the same dating principles as the ones for the African Surface (Guillocheau et al., 2015), etchplain/pediplain u2 was planated from the Late Eocene to the end of the Oligocene (40-23 Ma) and probably before the Late Oligocene weathering period (28-23 Ma), pediplain $\mathrm{l}$ around the Early Miocene (23-16 Ma), pediment $\mathrm{x}$ during the Late Miocene (11-5 Ma) and pediment y from Late Miocene (younger than $\mathrm{x}$ ) to Early Pliocene (10-3 Ma). Pediplain 1 is extensively duricrusted by laterites, which is consistent with a planation before the second major Cenozoic weathering period (Early to Middle Miocene). A Late Miocene age for pediments $\mathrm{x}$ is supported by the low amount of weathering of this landform and by the new ages of the weatherings available in Katanga (De Putter et al., 2015) which confirms a major uplift around 10.5-11 Ma, namely at the time of the pediment $\mathrm{x}$ erosion in this area. 
The successive palaeotopographies can be reconstructed (Fig. 10) by restoring the vertical displacement recorded by each stepped pediment/pediplain (see 2.1).

(1) We confirmed an initial nearly flat African Surface gently inclined toward the Atlantic Ocean during Eocene times with remnants of oldest relief (Taylor and Howard, 1998, Guillocheau et al., 2015) with a divide between the Atlantic Ocean and Indian Ocean base levels along the present-day western branch of the East African Rift. This implies that the present-day topography of Central Africa is younger than 40-30 Ma as already suggested by Bond (1978), Burke \& Gunnell (2008) or Roberts and White (2010).

(2) The uplift of the East African Dome and of the flanks of the western branch of the EAR - recorded by the stepping between the African Surface and the etchplain/pediplain u2 - start quite early with a quite long age range from 45 to $23 \mathrm{Ma}$ (and probably before $28 \mathrm{Ma}$ - see discussion above). The stratigraphic record of both the Atlantic Margin and Indian Margin confirms and pinpoints the timing of this uplift. Siliciclastic sediment budget measurements along the Atlantic Margin (Leturmy et al., 2003; Anka et al., 2010) - from northern Gabon to Angola - indicate a major sharp sediment rate increase around $34 \mathrm{Ma}$ and the birth of the three major present-day deltas: the Ogooué, Niger and Kwanza Deltas (Séranne and Anka, 2005; Anka et al., 2009). Along the Indian Ocean, the age of the first sediments from the two major deltas, the Rovuma and Rufiji Deltas, is not the same. The Rovuma Delta initiated around $34 \mathrm{Ma}$ (Eocene-Oligocene boundary, Salman and Abdula, 1995) and the Rufiji Delta occurred later around 23 Ma (Oligocene-Miocene boundary, Kajato et al., 1982). These Atlantic and Indian Ocean stratigraphic data suggest an uplift initiation of the East African Dome around 34 Ma. 
This uplift increased during Late Miocene times (11-6 Ma - incision of pediments $\mathrm{x}$ ), at time of the major reorganization of the EAR (e.g. MacGregor, 2015).

(3) The uplift of the Central African Atlantic Swell started later, with the stepping of pediplain I from the African Surface and etchplain/pediplain u2 that merged here. This uplift occurred during Early Miocene times (23-16 Ma) again confirmed by the stratigraphic record of the margins and thermochronological data in Gabon (Walgenwitz et al., 1992). A major unconformity is recorded during Burdigalian times (20-16 Ma) in the Ogooué Delta (Mougamba, 1999), southern Gabon (Walgenwitz et al., 1992) and along the Congo Delta (Massala, 1993).

Again this uplift increased during Late Miocene - Early Pliocene times (11-3 Ma incision of pediments $\mathrm{x}$ and $\mathrm{y}$ ), confirmed by the increase in the sediment supply in the Ogooué Delta (Mougamba, 1999).

(4) The uplift of the Congo Basin to its present-day elevation of $300 \mathrm{~m}$ was during Late Miocene - Early Pliocene (pediments $\mathrm{x}$ and $\mathrm{y}$ ) at the time of a major reorganization of the Congo Delta (northward shifting of the depocentres, Anka et al., 2009).

Using similar approaches (Guillocheau et al., 2015), the uplift of the Cameroon Dome and the Central African Rise started around 34 Ma (Oligocene-Eocene boundary). The growth of the Angola Mountains is different from the other domes and unfortunately few published data with ages are available on the margin to constrain its evolution. The uplift started during the Middle Miocene (Lunde et al., 1992), as evidenced by a major hiatus (Jackson et al., 2005) and increased from the Late Miocene to the present day as indicated by the truncation of the Late Miocene sediments (Jackson et al., 2005; Al-Hajri et al., 2009) and the uplifted Late Pleistocene marine terraces in the Benguela area 
(Guiraud et al., 2010). The timing of the Ethiopian dome is poorly constrained because of the few dated geomorphological and margin stratigraphic data.

\section{Very long wavelength deformations and mantle dynamics.}

5.1. Constraints provided by the geomorphology (Fig. 11)

Two wavelengths of deformation are characterized here using geomorphological constraints: a very long wavelength one which can be related to mantle dynamics (e.g. Braun, 2010; Burov and Gerya, 2014; Burke and Cannon, 2014; Colli et al., 2016) and a long wavelength resulting from lithospheric-scale deformations (e.g. Cloetingh and Burov, 2011; Burov, 2011). Since the pioneering works of Holmes (1944), it has already been suggested by several authors that mantle dynamic controls these very long deformations (Lithgow-Bertelloni and Silver, 1998; Gurnis et al., 2000 in Africa), for which Hager and Gurnis (1987) coined the term "Dynamic topography". Hartley et al. (1996) used a dual analysis of gravity anomalies and topography to suggest that these very long wavelength relief may not be completely isostatically compensated, one of the key-arguments for a dynamic topography origin (Braun, 2010; Colli et al., 2016).

The evolution through time of the very long wavelength deformations that have been characterized in this present work (Fig. 11) addresses several questions with regards to past mantle dynamics.

(1) Kinematics of mantle dynamic changes: Even though it was poorly dated onshore, the margin stratigraphy seems to record a quite fast uplift around 34 Ma for the Cameroon and East Africa Domes. Unfortunately, this time interval is also a major 
period of climate change with the initiation of polar caps on Antarctica coeval with a major cooling of the Earth (e.g. Zachos et al., 2001). The effect of this cooling is poorly understood with respect to the climate and surface processes of Africa. Researches agree that there was a minor aridification in South Africa at that time (Tyson and Partridge, 2000), but these data are scarce and quite unreliable. The eustatic effects of this major cooling are also debated (Miller et al., 2008), with a sea level fall ranging between 50 and $100 \mathrm{~m}$ which is not enough to control the birth of new deltas and the previously discussed sharp increase in the sediment supply. In the present-day state of our knowledge, we may assume a climate-forced uplift for the unconformities recorded all around Central Africa at $34 \mathrm{Ma}$, thereby following Burke and Gunnell (2008).

Our results imply an increase in mantle upwelling beneath Central Africa around 30 and $40 \mathrm{Ma}$ that may be or not the consequence of temporal changes in asthenosphere flows beneath Central and Austral Africa as suggested by Colli et al. (2014), or a fast migration of the upper part of the convection cell of the African superswell controlling the East African Dome following Forte et al. (2010) or the earlier stage of a mantle plume effect according to Koptev et al. (2015). This also implies for the same time interval (40-30 Ma) the initiation of a mantle upwelling beneath the Cameroon Dome as the magmatic activity already started 40 to 30 Ma before (emplacement of the "younger granites" in the Cameroon Volcanic Line since $66 \mathrm{Ma}$, see Njonfang et al, 2011 for a review). However, the simultaneous uplift of the Cameroon Dome, the Central African Rise and the East African Dome is supported by the seismic tomography data of Reusch et al. (2010) which explained the Cameroon Volcanic Line by an edge flow convecting along the northern boundary of the Congo craton lithosphere coming from the East African mantle upwelling. 
(2) Spatial distribution changes in mantle dynamics: The second surprising result concerns the increase in the wavelength of the deformation from 30-40 Ma to 10 Ma. Around $34 \mathrm{Ma}$, two major domes, the Cameroon and the East Africa Dome, and the Central African Rise located in between were initiated (Fig. 11) and later on - between 10 and $3 \mathrm{Ma}$ - the wavelength increased with an uplift of all of Central Africa. This again implies a change in mantle dynamics with a progressive evolution from localized zones of uplift (the two domes) to a larger Central African-scale regime of mantle convection.

The nature of the deformation controlling the Central African Atlantic Swell and the Central African Rise might be (according to their wavelengths) of lithospheric-origin. But this is quite uncertain. It is quite difficult at the moment to quantify the relative importance of the isostatic response to erosion (Gilchrist et al., 1994, Van Der Beek et al., 2002 in Africa), ridge push effects or other processes involving margin compression (Yamato et al., 2013) in the growth of the marginal bulges that are characteristic of several passive margins in the world (elevated passive margins of Japsen et al., 2012 and Green et al., 2014). The age of uplift in the Central African Atlantic Swell (20-16 Ma) did not correspond (1) to any major climatic or eustatic changes (Zachos et al., 2011; Miller et al., 2005) that could trigger a modification of the erosion processes at the origin of an instantaneous isostatic response or (2) to a major change in sea-floor spreading (Colli et al., 2014) which may induce a ridge push effect. More global studies, at least at continent-scale, are required to understand these margin deformations.

5.2. Discussion: comparison with the available dynamic topographic models. 
One of the major challenges in mantle dynamic studies is to simulate the past mantle convection starting from the present-day relationships between the mantle convection and topography. Several studies have been carried out (Conrad \& Gurnis, 2003; Moucha et al., 2011), with different results according to the boundary conditions of the models (mantle viscosity structure, role of subductions, etc.).

One such study was carried out in Africa to reconstruct dynamic topography over the past 30 Ma (Moucha et al., 2011 based on the model of Forte et al., 2010). Seven timeslices are available including the present-day (steps of $5 \mathrm{Ma}$ ). This model predicts growth of the East African Dome and subsidence of the Congo Basin since 25 Ma. The rate of change of dynamic topography for the Central African Atlantic Swell and the Angola Mountains is low and constant since 25 Ma. No dynamic topography effect is modelled beneath the Cameroon Dome.

This model does not fit our data. No subsidence occurred along Central Africa since the lowermost Early Cenozoic as suggested by the stratigraphic and subsidence analysis of the Congo Basin (Linol et al., 2015). The only point of agreement concerns the growth of the East African Dome even though our results suggest an earlier dome initiation.

Other models (Downey and Gurnis, 2009; Crosby et al., 2010) suggested that the Congo Basin was a subsiding domain in response to mantle convection draw-down. Our result do not support this interpretation, in agreement with Buiter et al. (2012) which has shown on gravity and seismic tomography evidences that the sublithospheric mantle was not efficient for controlling the basin subsidence.

\section{Conclusions}


The objective of this study was to develop a new approach based on very-long wavelength deformations using planation surfaces to constrain the past mantle dynamic evolution.

1. The African relief is shaped by two major types of planation surfaces: etchplains which correspond to the weathering of surfaces by laterites and pediplains/pediments. Other surfaces exist: wave-cut platforms and buried-exhumed glacial surfaces. These planation surfaces are stepped along plateaus with various elevations.

2. The stepping of the pediment-type planation surfaces records a local base level fall due to local uplift: each pediment flat surface is a local base level as indicated by the adjustment of upscarp incised rivers to this surface, successive flat surfaces can be tilted, etc.

3. Central Africa is an extensive etchplain-type weathering surface from the uppermost Cretaceous (70 Ma) to the Middle Eocene (45 Ma) with a paroxysm around the Early Eocene Climatic Optimum. The restoration of the African Surface in Central Africa suggests low-elevation planation surfaces connected to the Atlantic Ocean and Indian Ocean with a divide located around the present-day eastern branch of the East African Rift.

4. The present-day topography of Central Africa is younger than 40-30 Ma. It results from very long wavelength deformations $(1000-2000 \mathrm{~km})$ that induced (1) the growth of the Cameroon Dome and East African Dome since $34 \mathrm{Ma},(2)$ the uplift of the lowelevation (300 m) Congo Basin since 20-10 Ma and (3) the growth of the Angola 
Mountains since 15-12 Ma up to Pleistocene times. Some long wavelength deformations (several $100 \mathrm{~km}$ ) controlled smaller relief (bulges), (1) the low elevation central African Rise since $34 \mathrm{Ma}$ and (2) the Atlantic Swell since 20-16 Ma.

5. Those very long wavelength deformations record past mantle dynamics, with a sharp increase of mantle upwelling around $34 \mathrm{Ma}$ and an increase of the very long wavelength of the deformation and then of the mantle convection beneath Central Africa around 10$3 \mathrm{Ma}$.

6. In Central Africa, the bimodal topography results from a dual mantle uplift one starting around $34 \mathrm{Ma}$ for the relief with an elevation around 900-1100 $\mathrm{m}$ and a second one starting between 10 and 3 Ma for the relief with an elevation around 300-400 m (Congo Basin).

\section{Acknowledgments}

This work was supported by the French National Research Agency (ANR), TopoAfrica Project (grant number 08-BLAN_0247). We would like to thank Jean Braun (GFZ, Potsdam), Dominique Chardon and Delphine Rouby (GET, Toulouse University, IRD and CNRS) for fruitful discussions. Dominique organized a field trip in Mali (Mandingues Plateau) that was at the origin of this research. Thomas Croissant, a PhD student at Géosciences-Rennes, designed a software to map the African Surface. Many thanks to him. 
We are very grateful to Yanni Gunnell and Peter Japsen for their critical comments that improved the early version of the manuscript. We would like to thank Hans-Peter Bunge for inviting us to this special issue and for editing the final version of the manuscript. 


\section{References}

Adeleye, D.R., 1973. Origin of ironstones, an example from the Middle Niger Valley, Nigeria. Journal of Sedimentary Petrology 43, 709-727.

Al-Hajri, Y., White, N., Fishwick, S., 2009. Scales of transient convective support beneath Africa. Geology 37, 883-886.

Anka, Z., Séranne, M., di Primio, R., 2010. Evidence of a large upper-Cretaceous depocentre across the Continent-Ocean boundary of the Congo-Angola basin. Implications for palaeodrainage and potential ultra-deep source rocks. Marine and Petroleum Geology 27, 601611.

Anka, Z., Séranne, M., Lopez, M., Scheck-Wenderoth, M., Savoye, B., 2009. The long-term evolution of the Congo deep-sea fan: A basin-wide view of the interaction between a giant submarine fan and a mature passive margin (ZaiAngo project). Tectonophysics 470, 4256.

Beauvais, A., Ruffet, G., Hénocque, O., Colin, F., 2008. Chemical and physical erosion rhythms of the West African Cenozoic morphogenesis: The ${ }^{39} \mathrm{Ar}-40 \mathrm{Ar}$ dating of supergene $\mathrm{K}-\mathrm{Mn}$ oxides. Journal of Geophysical Research 113, F04007.

Beauvais, A., Chardon, D., 2013. Modes, tampo, and spatial variability of Cenozoic cratonic denudation: The West African example. Geochemistry, Geophysics, Geosystems 14, 15901608.

Bessin, P., Guillocheau, F., Robin, C., Schroëtter, J.M., Bauer, H., 2015. Planation surfaces of the Armorican Massif (western France): Denudation chronology of a Mesozoic land surface twice exhumed in response to relative crustal movements between Iberia and Eurasia. Geomorphology 233, 75-91.

Bond, G., 1978. Evidence for Late Tertiary uplift of Africa relative to North America, 
Australia and Europe. Journal of Geology 86, 47-65.

Boudouresque, L., Dubois, D., Lang, J., Trichet, J., 1982. Contribution à la stratigraphie et à la paléogéographie de la bordure occidentale du bassin des Iullemmeden au Crétacé supérieur et au Cénozoïque (Niger et Mali, Afrique de l'Ouest). Bulletin de la Société géologique de France (7) XXIV, 685-695.

Braucher, R., Bourlès, D.L., Brown, E.T., Colin, F., Muller, J.P., Braun, J.J., Delaune, M., Edou Minko, A., Lescouet, C., Raisbeck, G.M., Yiou, F., 2000. Application of in-situ production cosmogenic10Be and 26Al to the study of lateritic soil development in tropical forest: theory and examples from Cameroon and Gabon. Chemical Geology 170, 95-111.

Braun, J., 2010. The many surface expressions of mantle dynamics. Nature Geoscience 3, 825-833.

Braun, J., Guillocheau, F., Robin, C., Baby, G., Jelsma, H., 2014. Rapid erosion of the Southern African Plateau as it climbs over a mantle superswell. Journal of Geophysical Research: Solid Earth 119, 6093-6112.

Braun, J., Mercier, J., Guillocheau, F. \& Robin, C., 2016. A simple model for regolith formation by chemical weathering. Journal of Geophysical Research Earth Surface 121, 2140-2171.

Bremer, H., 1993. Etchplanation; review and comments of Büdel's model. Zeitschrift für Geomorphologie. Supplementband 92, 189-200.

Buckle, C., 1978. Landforms in Africa: An introduction to geomorphology. Longmans, London.

Büdel, J., 1957. Sie "Doppelten Einebnungsflächen" in der feuchten Tropen. Zeitschrift für Geomorphologie N.F. 1, 201-286.

Büdel, J., 1982. Climatic geomorphology (Translated by Fischer, L. and Busche, D.). Princeton University Press, Princeton, New Jersey, United States.

Buiter, S.J.H., Steinberger, B., Medvedev, S., Tetreault, J.L., 2012. Could the mantle have 
caused subsidence of the Congo Basin? Tectonophysics 514-517, 62-80.

Burke, K., 1996. The African Plate. South African Journal of Geology 99, 339-410.

Burke, K. and Cannon, M.J., 2014. Plume-plate interaction. Canadian Journal of Earth Sciences 51, 208-221.

Burke, K., Gunnell, Y., 2008. The African erosion surface: A continental-scale synthesis of geomorphology, tectonics and environmental change over the past 180 million years. Geological Society of America, Memoir 201, 66.

Burke, K., MacGregor, D.S., Cameron, N.R., 2003. Africa's petroleum systems: four tectonic "aces" in the past 600 million years, In: Arthur, T.J., MacGregor, D.S., Cameron, N.R. (Eds.), Petroleum geology of Africa: new themes and developing technologies. Geological Society, London, Special Publications, pp. 21-60.

Burke, K., Wilson, J.T., 1972. Is the African Plate stationary. Nature 239, 387-390.

Burov, E., Gerya, T., 2014. Asymmetric three-dimensional topography over mantle plumes. Nature 513, 85-89.

Burov, E.B., 2011. Rheology and strength of the lithosphere. Marine and Petroleum Geology $28,1402-1443$.

Cahen, L., 1954. Géologie du Congo belge. Vaillant-Carmanne, Liège.

Catuneanu, O., Wopfner, H., Eriksson, P.G., Cairncross, B., Rubidge, B.S., R.M.H., S., Hancox, P.J., 2005. The Karoo basins of south-central Africa. Journal of African Earth Sciences 43, 211-253.

Chamley, H., 1989. Clay sedimentology. Springer-Verlag, Berlin Heidelberg.

Chardon, D., Chevillotte, V., Beauvais, A., Grandin, G., Boulangé, B., 2006. Planation, bauxite and epeirogeny: One or two paleosurfaces on the West African margin? Geomorphology 82, 273-282.

Chételat, E.d., 1938. Le modelé latéritique de l'Ouest de la Guinée française Revue de 
Géographie physique et de Géologie dynamique 11, 5-120.

Cloetingh, S., Burov, E., 2011. Lithospheric folding and sedimentary basin evolution: a review and analysis of formationmechanisms. Basin Research 23, 257-290.

Cockburn, H.A.P., Brown, R.W., Summerfield, M.A., Seidl, M.A., 2000. Quantifying passive margin denudation and landscape development using a combined fission-track thermochronology and cosmogenic isotope analysis approach. Earth and Planetary Science Letters 179, 429-435.

Colli, L., Stotz, I., Bunge, H.P., Smethurst, M.A., Clark, S., Iaffaldano, G., Tassara, A., Guillocheau, F., Blanchi, M.C., 2014. Rapid South Atlantic spreading changes and coeval vertical motion in surrounding continents: Evidence for temporal changes of pressuredriven upper mantle flow. Tectonics 32, 1304-1321.

Colli, L., Ghelichkhan, S., Bunge, H.-P., 2016. On the ratio of dynamic topography and gravity anomalies in a dynamic Earth. Geophysical Research Letters 43, 2510-2516.

Conrad, C.P., Gurnis, M., 2003. Seismic tomography, surface uplift, and the breakup of Gondwanaland: Integrating mantle convection backwards in time. Geochemistry, Geophysics, Geosystems 4 (3) 1031.

Crosby, A.G., Fishwick, S., White, N., 2010. Structure and evolution of the intracratonic Congo Basin. Geochemistry, Geophysics, Geosystems 11, Q06010.

Dauteuil, O., Bouffette, J., Toteu, F., 2009. The changing faces of Africa. Elements of African geology. Commission for the Geological Map of the World, Paris.

Davis, W.M., 1899. The geographical cycle. Geographical Journal 14, 481-504.

De Putter, T., Ruffet, G., Yans, J., Mees, F., 2015. The age of supergene manganese deposits in Katanga and its implications for the Neogene evolution of the African Great Lakes Region. Ore Geology Reviews 71, 350-362.

de Wit, M., 2007. The Kalahari Epeirogeny and climate change: differentiating cause and 
effect from core to space. South African Journal of Geology 110, 367-392.

Decker, J.E., Niedermann, S., de Wit, M.J., 2013. Climatically influenced denudation rates of the southern African plateau: Clues to solving a geomorphic paradox. Geomorphology $190,48-60$.

Deller, M.E., 2012. Lateritic paleosols of N.E. Africa: A remote sensing study. Open University, London, p. 416.

Dohrenwend, J.C., Parsons, A.J., 2009. Pediments in arid environments, In: Parsons, A.J., Abrahams, A.D. (Eds.), Geomorphology of desert environments. Springer Science+Business Media B.V., Berlin-Heidelberg, pp. 377-411.

Downey, N.J., Gurnis, M., 2009. Instantaneous dynamics of the cratonic Congo basin. Journal of Geophysical Research 114, B06401.

Ebert, K., 2009. Terminology of long-term geomorphology: a Scandinavian perspective. Progress in Physical Geography 33, 163-182.

Fairbridge, R.W., 1952. Marine erosion, 7th Pacific Science Congress, New Zaeland 1949, Pacific Science Associations Proceedings, pp. 347-358.

Forte, A.M., Quéré, S., Moucha, R., Simmons, N.A., Grand, S.P., Mitrovica, J.X., Rowley, D.B., 2010. Joint seismic-geodynamic-mineral physical modelling of African geodynamics: A reconciliation of deep-mantle convection with surface geophysical constraints. Earth and Planetary Science Letters 295, 329-341.

Gilbert, G.K., 1890. Lake Bonneville. U.S. Geological Survey Monograph 1, 438.

Gilchrist, A.R., Kooi, H., Beaumont, C., 1994. Post-Gondwana geomorphic evolution of southwestern Africa: Implications for the controls on landscape development from observations and numerical experiments. Journal of Geophysical Research 99, 1221112228.

Grandin, G., 1976. Aplanissements cuirassés et enrichissements des gisements de 
manganèse dans quelques régions d'Afrique de l'Ouest. Mémoire de l'Office de la Recherche Scientifique et Technique Outre-Mer (ORSTOM) 82, 275.

Green, P.F., Lidmar-Bergström, K., Japsen, P., Bonow, J.M., Chalmers, J.A. 2013. Stratigraphic landscape analysis, thermochronology and the episodic development of elevated passive continental margins. Geological Survey of Denmark and Greenland Bulletin 2013/30, 150.

Guillocheau, F., Chelalou, R., Linol, B., Dauteuil, O., Robin, C., Mvondo, F., Callec, Y., Colin, J.P., 2015. Cenozoic landscape evolution in and around the Congo Basin: Constraints from sediments and planation surfaces, In: de Wit, M.J., Guillocheau, F., de Wit, M.C.J. (Eds.), Geology and Resource Potential of the Congo Basin. Springer-Verlag, Berlin Heidelberg, pp. 271-313.

Guiraud, M., Buta-Neto, A., Quesne, D., 2010. Segmentation and differentiated post-rift uplift at the Angola margin as recorded by transform-rifted Benguela and oblique-toorthogonal-rifted Kwanza basins. Marine and Petroleum Geology 27, 1040-1068.

Guiraud, R., Maurin, J.C., 1992. Early Cretaceous rifts of Western and Central Africa: an overview. Tectonophysics 213, 153-168.

Gurnis, M., Mitrovica, J.X., Ritsema, J., van Heijst, H.J., 2000. Constraining mantle density structure using geological evidence of surface uplift rates: The case of the African Superplume. Geochemistry, Geophysics, Geosystems 1, 1999GC000035.

Gutzmer, J., Du Plooy, A.P., Beukes, N.J., 2012. Timing of supergene enrichment of low-grade sedimentary manganese ores in the Kalahari Manganese Field, South Africa. Ore Geology Reviews 47, 136-153.

Hager, B. H., and M. Gurnis (1987), Mantle convection and the state of the earth' interior, Reviews of Geophysics, 25, 1277-285.

Harrison, C.G.A., Miskell, K.J., Brass, G.W., Saltzman, E.S., Slaon II, J.L., 1983. Continental 
hypsometry. Tectonics 2, 357-377.

Hartley, R.W., Watts, A.B., Fairhead, J.D., 1996. Isostasy of Africa. Earth and Planetary Science Letters 137, 1-18.

Heine, C., Müller, R.D., Steinberger, B., DiCaprio, L., 2010. Integrating deep Earth dynamics in paleogeographic reconstructions of Australia. Tectonophysics 483, 135-150.

Jackson, M.P.A., Hudec, M.R., Hegarty, K.A., 2005. The great West African Tertiary coastal uplift: Fact or fiction? A perspective from the Angolan divergent margin. Journal of Geophysical Research 24, TC6014.

Japsen, P., Chalmers, J.A., Green, P.F., Bonow, J.M., 2012. Elevated, passive continental margins: Not rift shoulders, but expressions of episodic, post-rift burial and exhumation. Global and Planetary Change 100, 153-171.

Japsen, P., Green, P.F., Bonow, J.M., Erlström, M., 2016. Episodic burial and exhumation of the southern Baltic Shield: Epeirogenic uplifts during and after break-up of Pangaea. Gondwana Research 35, 357-377..

Jessen, 0., 1936. Reisen und Forschungen in Angola. Verlag von Dietrich Reimer, Berlin.

Kajato, H.K., 1982. Gas strike spurs search for oil in Tanzania. Oil \& Gas Journal Mars 15, 123-131.

King, L.C., 1949. On the age of African land-surfaces. Quaterly Journal of the Geological Society, London 104, 439-459.

King, L.C., 1953. Canons of landscape evolution. Bulletin of the Geological Society of America, 721-752.

King, L.C., 1962. Morphology of the Earth. Oliver and Boyd, Edinburgh.

Koptev, A., Calais, E., Burov, E., Leroy, S., Gerya, T., 2015. Dual continental rift systems generated by plume-lithosphere interaction. Nature Geoscience 8, 388-392.

Leturmy, P., Lucazeau, F., Brigaud, F., 2003. Dynamic interactions between the gulf of Guinea 
passive margin and the Congo River drainage basin: 1. Morphology and mass balance. Journal of Geophysical Research 108, B8, 2383.

Lidmar-Bergström, K., 1996. Long term morphotectonic evolution in Sweden. Geomorphology 16, 33-59.

Lidmar-Bergström, K., Bonow, J.M., Japsen, P., 2013. Stratigraphic Landscape Analysis and geomorphological paradigms: Scandinavia as an example of Phanerozoic uplift and subsidence. Global and Planetary Change 100, 153-171.

Lighgow-Bertelloni, C., Silver, P.G., 1998. Dynamic topography, plate driving forces and theAfrican superswell. Nature 395, 269-272.

Linol, B., de Wit, M.J., Guillocheau, F., Robin, C., Dauteuil, 0., 2015. Multiphase Phanerozoic subsidence and uplift history recorded in the Congo Basin: A complex successor basin, In: de Wit, M.J., Guillocheau, F., de Wit, M.C.J. (Eds.), Geology and Resource Potential of the Congo Basin. Springer-Verlag, Berlin Heidelberg, pp. 213-227.

Lunde, G., Aubert, K., Lauritzen, O., Lorange, E., 1992. Tertiary uplift of the Kwanza Basin in Angola, Géologie Africaine : Coll. Géol. Libreville, recueil des Communications, 6-8 May 1991. Elf-Aquitaine Editions, Pau, pp. 99-117.

Mabbutt, J.A., 1966. Mantle-controlled planation of pediments. American Journal of Science $264,78-91$.

Macgregor, D., 2015. History of the development of the East African Rift System: A series of interpreted maps through time. Journal of African Earth Sciences 101, 232-252.

Marker, M.E., McFarlane, M.J., Wormald, R.J., 2002. A laterite profile near Albertinia, Southern Cape, South Africa: its significance in the evolution of the African Surface. South African Journal of Geology 105, 67-74.

Massala, A., 1993. Le Crétacé supérieur et le Tertiaire du bassin côtier congolais. Biochronologie et stratigraphie séquentielle. Université de Bourgogne, Dijon, p. 392. 
Matmon, A., Mushkin, A., Enzel, Y., Grodek, T., Ream, A., 2013. Erosion of a granite inselberg, Gross Spitzkoppe, Namib Desert. Geomorphology 201, 52-59.

Maud, R.R., 1965. Laterite and lateritic soil in coastal Natal, South Africa. Journal of Soil Science 16, 60-72.

McFarlane, M.J., 1976. Laterite and landscape. Academic Press, New York.

McKenzie, D., Weiss, N., 1975. Speculations on the thermal and tectonic history of the Earth. Geophysical Journal Royal astronomical Society 42, 131-174.

Michel, P., 1973. Les bassins des fleuves Sénégal et Gambie, étude géomorphologique. Mémoire de l'Office de la Recherche Scientifique et Technique Outre-Mer (ORSTOM) 63, $752 \mathrm{p}$.

Migoń, P., 2004a. Planation surfaces, In: Goudie, A.S. (Ed.), Encyclopedia of Geomorphology. Routledge, London, pp. 788-792.

Migoń, P., 2004b. Peneplain, In: Goudie, A.S. (Ed.), Encyclopedia of Geomorphology. Routledge, London, pp. 771-772.

Migoń, P., 2004c. Etching, Etchplain and Etchplanation, In: Goudie, A.S. (Ed.), Encyclopedia of Geomorphology. Routledge, London, pp. 345-347.

Miko Dit Angoula, I., 1999. Dynamique sédimentaire des formations détritiques et ligniteuses du continental terminal dans le bassin des Iullemmeden (Niger), Département de Géologie. Université Abdou Moumouni, Niamey, p. 328.

Miller, K.G., Kominz, M.A., Browning, J.V., Wright, J.D., Mountain, G.S., Katz, M.E., Sugarman, P.J., Cramer, B.S., Christie-Blick, N., Pekar, S.F., 2005. The Phanerozoic record of global sea-level change. Science 310, 1293-1298.

Miller, K.G., Wright, J.D., Katz, M.E., Browning, J.V., Cramer, B.S., Wade, B.S., Mizintseva, S.F., 2008. A view of Antarctic ice-sheet evolution from sea-level and deep-sea isotope changes during the Late Cretaceous-Cenozoic, In: Cooper, A.K., Barrett, P.J., Stagg, H., 
Storey, B., Stump, E., Wise, W., editorialTeam, t.I. (Eds.), Antarctica: A Keystone in a Changing World. Proceedings of the 10th International Symposium on Antarctic Earth Sciences. The National Academies Press, Washington, DC, pp. 55-70.

Millot, G., 1981. Weathering sequences. "Climatic" planations. Leveled surfaces and paleosurfaces, In: van Olphen, H., Veniale, F. (Eds.), Proceedings of the VII International Clay Conference, Bologna and Pavia. Elsevier, Amsterdam, pp. 585-593.

Moucha, R., Forte, A.M., 2011. Changes in African topography driven by mantle convection. Nature Geoscience 4, 707-712.

Mougamba, R., 1999. Chronologie et architecture des systèmes turbiditiques cénozoïque du prisme sédimentaire de l'Ogooué (Marge nord-Gabon). Université de Lille 1, Villeneuved'Ascq, p. 285.

Mucke, A., 2000. Environmental conditions in the Late Cretaceous African Tethys: conclusions from a microscopic-microchemical study of ooidal ironstones from Egypt, Sudan and Nigeria. Journal of African Earth Sciences 30, 25-46.

Nicolini, P., 1967. Remarques comparatives sur quelques éléments sédimentologiques et paléogéographiques liés aux gisements de fer oolithiques du Djebel Ank (Tunisie) et de Lorraine (France). Mineralium Deposita 2, 95-101.

Njonfang, E., Nono, A., Kamgang, P., Ngako, V., Tchoua, F., 2011. Cameroon Line alkaline magmatism (central Africa): A reappraisal, In: Baccaluva, L., Bianchini, G., Wilson, M. (Eds.), Volcanism and Evolution of the African Lithosphere. Geological Society of America, Special Paper, pp. 173-191.

Njonfang, E., Nono, A., Kamgang, P., Ngako, V., Tchoua, F.M., 2011. Cameroon Line alkaline magmatism (central Africa): A reappraisal, In: Beccaluva, L., Bianchini, G., Wilson, M. (Eds.), Volcanism and Evolution of the African Lithosphere. Geological Society of America, Special Paper, pp. 173-191. 
Ollier, C.D., 1960. The inselberghs of Uganda. Zeitschrift Für Geomorphologie 4, 43-52.

Orme, A.R., 2013. 1.12 Denudation, Planation, and Cyclicity: Myths, Models, and Reality, In: Shroder, J.F. (Ed.), Treatise on Geomorphology. Academic Press, San Diego, pp. 205-232.

Peulvast, J.P., Sales, V.C., 2004. Stepped surfaces and palaeolandforms in the northern Brazilian «Nordeste»: constraints on models of morphotectonic evolution. Geomorphology 62, 89-122.

Pickford, M., 2015. Cenozoic Geology of the Northern Sperrgebiet, Namibia, accenting the Palaeogene. Communications of the Geological Survey of Namibia 16, 10-104.

Pugh, J.C., 1954. High-level surfaces in the eastern Highlands of Nigeria. South African Geographical Journal 36, 31-42.

Ramsay, A.C., 1846. On the denudation of South Wales and the adjacent countries of England. Memoir of the Geological Survey of Great Britain 1, 297-335.

Reusch, A.M., Nyblade, A.A., Wiens, D.A., Shore, P.J., Ateba, B., Tabod, C.T., Nnange, J.M., 2010. Upper mantle structure beneath Cameroon from body wave tomography and the origin of the Cameroon Volcanic Line. Geochemistry, Geophysics, Geosystems 11, Q10W07.

Riser, J., 1975. Les modelés des granites du Jbel Sarho oriental (Anti-Atlas oriental). Revue de Géographie physique et de Géologie dynamique (2) XVII, 61-72.

Roberts, G.G., White, N., 2010. Estimating uplift rate histories from river profiles using African examples. Journal of Geophysical Research 115.

Salama, W., El Aref, M., Gaupp, R., 2014. Facies analysis and palaeoclimatic significance of ironstones formed during the Eocene greenhouse. Sedimentology 61, 1594-1624.

Salard-Cheboldaeff, M., Dejax, J., 1991. Evidence of Cretaceous to Recent West African intertropical vegetation from continental sediment spore-pollen analysis. Journal of African Earth Sciences 12, 353-361.

Salman, G., Abdula, I., 1995. Development of the Mozambique and Ruvuma sedimentary 
basins, offshore Mozambique. Sedimentary Geology 96, 7-41.

Schumm, S.A., 1993. River response to baselevel change: Implications for sequence stratigraphy. Journal of Geology 101, 279-294.

Schwarz, T., Germann, K., 1999. Weathering surfaces, laterite-derived sediments and associated mineral deposists in north-east Africa. Special Publications of the International Association of Sedimentologists 27, 367-390.

Séranne, M., Anka, Z., 2005. South Atlantic continental margins of Africa: A comparison of the tectonic vs climate interplay on the evolution of equatorial west Africa and SW Africa margins. Journal of African Earth Sciences 43, 283-300.

Siesser, W.G., Miles, G.A., 1979. Calcareous nannofossils and planktic foraminifers in Tertiary Limestones, Natal and Eastern Cape, South Africa. Annals of the South African Museum $79,139-158$.

Simon, B., 2015. Rift du Lac Albert, Ouganda, Rift Est Africain : Déformation, érosion, sédimentation et bilan de matière depuis 17 Ma. Université de Rennes 1, Rennes, p. 403.

Strudley, M.W., Murray, A.B., Haff, P.K., 2006. Regolith thickness instability and the formation of tors in arid environments. Journal of Geophysical Research 111, F03010.

Tanner, L.H., Khalifa, M.A., 2010. Origin of ferricretes in fluvial-marine deposits of the Lower Cenomanian Bahariya Formation, Bahariya Oasis, Western Desert, Egypt. Journal of African Earth Sciences 56, 179-189.

Tardy, Y., 1997. Petrology of laterites and tropical soils. A.A. Balkema, Rotterdam.

Tator, B.A., 1952. Pediment characteristics and terminology; Part 1, Pediment characteristics. Annals of the Association of American Geographers 42, 295-317.

Tator, B.A., 1953. Pediment characteristics and terminology; Part 2, Terminology. Annals of the Association of American Geographers 43, 47-53.

Taylor, R.G., Howard, K.W.F., 1998. Post-Palaeozoic evolution of weathered landsurfaces in 
Uganda by tectonically controlled deep weathering and stripping. Geomorphology 25, 173-192.

Théveniaut, H., 2012. Recherches et applications du paléomagnétisme et du magnétisme des roches aux problématiques d'un service géologique national. Université d'Orléans, Orléans, p. t1: 79.

Thomas, M.F., 1989a. The role of etch processes in landform developments: I. Etching concepts and their applications. Zeitschrift für Geomorphologie N.F. 33, 129-142.

Thomas, M.F., 1989b. The role of etch processes in landform developments: II. Etching and the formation of relief. Zeitschrift für Geomorphologie N.F. 33, 257-274.

Thomas, M.F., 1994. Geomorphology in the tropics; a study of weathering and denudation in low latitudes. John Wiley and Sons, Chichester, United Kingdom.

Thorn, C.E., 2004. Cryoplanation, In: Goudie, A.S. (Ed.), Encyclopedia of Geomorphology. Routledge, London, pp. 204-205.

Tooth, S., Rodnight, H., Duller, G.A.T., McCarthy, T.S., Marren, P.M., Brandt, D., 2007. Chronology and controls of avulsion along a mixed bedrock-alluvial river. Geological Society of America Bulletin 119, 452-461.

Twidale, C.R., Bourne, J.A., 1998. Multistage landform development, with particular reference to cratonic bornhardt. Geografiska Annaler. Series A, Physical Geography 80, 79-94.

Twidale, C.R., Bourne, J.A., 2013a. Pediments as etch forms: implications for landscape evolution. Journal of Geology 121, 607-622.

Twidale, C.R., Bourne, J.A., 2013b. Do pediplains exist? Suggested criteria and examples. Zeitschrift für Geomorphologie, NF 57, 411-428.

Tyson, P.D., Partridge, T.C., 2000. Evolution of Cenozoic climates, In: Partridge, T.C., Maud, R.R. (Eds.), The Cenozoic of Southern Africa. Oxford University Press, Oxford, pp. 371- 
387.

Van Der Beek, P.A., Summerfield, M.A., Braun, J., Brown, R.W., Fleming, A., 2002. Modeling postbreakup landscape development and denudational history across the southeast African (Drakensberg Escarpment) margin. Journal of Geophysical Research 107, B12, 2351.

Van Houten, F.B., 1992. Review of Cenozoic ooidal ironstones. Sedimentary Geology 78, 101110.

van Niekerk, H.S., Gutzmer, J., Beukes, N.J., Phillips, D., Kiviets, G.B., 1999. An ${ }^{40} \mathrm{Ar} /{ }^{39} \mathrm{Ar}$ age of supergene K-Mn oxyhydroxides soil profile on the Highveld of South Africa. South African Journal of Science 95, 450-454.

Vasconcelos, L., Brimhall, G.H., Becker, T.A., Rennes, P.R., 1994. ${ }^{40} \mathrm{Ar} /{ }^{39} \mathrm{Ar}$ analysis of supergene jarosite and alunite: Implications to the paleoweathering history of the western USA and West Africa. Geochimica et Cosmochimica Acta 58, 401-420.

Walgenwitz, F.R., Richert, J.P., Charpentier, P., 1992. Southwest African plate margin: Thermal history and geodynamical implications, In: Poag, C.W., Graciansky, P.C.d. (Eds.), Geologic evolution of Atlantic continental rises. Van Nostrand Reinhold, New York, pp. 20-45.

Wayland, E.J., 1933. Peneplains and some other erosional platforms. Note1. Annual Report Bulletin, Protectorate of Uganda, Geological Survey, Department of Mines, 77-79.

Whitaker, C.R., 1979. The use of the term 'pediment' and related terminology. Zeitschrift für Geomorphologie N.F. 23, 427-439.

White, K., 2004. Pediment, In: Goudie, A.S. (Ed.), Encyclopedia of Geomorphology. Routledge, London, pp. 768-770.

Widdowson, M., 1997. The geomorphological and geological importance of palaeosurfaces, In: Widdowson, M. (Ed.), Palaeosurfaces: Recognition, reconstruction and 
palaeoenvironmental interpretation. Geological Society Special Publication, London, pp. $1-12$.

Yamato, P., Husson, L., Becker, T.W., Pedoja, K., 2013. Passive margins getting squeezed in the mantle convection vice. Tectonics $32,1-12$.

Zachos, J., Pagani, M., Sloan, L., Thomas, E., Billups, K., 2001. Trends, rhythms, and aberrations in global climate 65 Ma to present. Science 292, 686-693. 


\section{FIGURE CAPTIONS}

Fig. 1: Onshore-offshore topography of Africa. a: DEM of Africa with the location of the geographical names cited in the text. b: elevation distribution of Africa showing a bimodal pattern (from Dauteuil et al., 2008).

Fig. 2: Main characteristics of the etchplains. a: mantled etchplain with duricrusts. b: stripped etchplain with inselbergs.

Fig. 3: Main characteristics of the pediments and pediplains. a: type pediment profile and variability. b: map view variability of the pediment shape. c: the concept of a pediment system.

Fig. 4: Planation surfaces of the case examples of the Jos Plateau (a) and Cameroon Highlands (b) (see Fig. 1 for location). a: stepped pediments at time t (mostly presentday geometry). b: reconstructions before the uplift (time $t-n$ ).

Fig. 5: Stepped planation surfaces. a: characteristic distribution of the stepped planation surfaces on the African plateaus. b: different scenarios of stepped pediment formation.

Fig. 6: Stepped pediments: arguments for an uplift record.

Fig. 7: Stepped planation surfaces on the Congolese side of the East African Dome (North Kivu Province). a: map of the planation surfaces - the circles shows the increase of the degradation of the flat surfaces from pediplain x (preserved), pediplain l (moderately 
degraded) to etchplain/pediplain u2 (highly degraded) - the arrows indicate examples of incised rivers adjusted to the flat surfaces of the pediments/pediplains - b: projected regional topographic profiles and landform interpretation (see Fig. 1 for location).

Fig. 8: Age of the main weathering periods in Africa and the age of the African Surface.

Fig. 9: Present-day elevation map of the African Surface in Central Africa .

Fig. 10: Synthetic evolution of Central Africa along an E-W- transect from northern Gabon to southern Kenya crossing through Uganda (see Fig. 1 for location).

Fig. 11: Growth of the topography of Central African since $50 \mathrm{Ma}$ - constraints for mantle dynamics in Cenozoic times. 


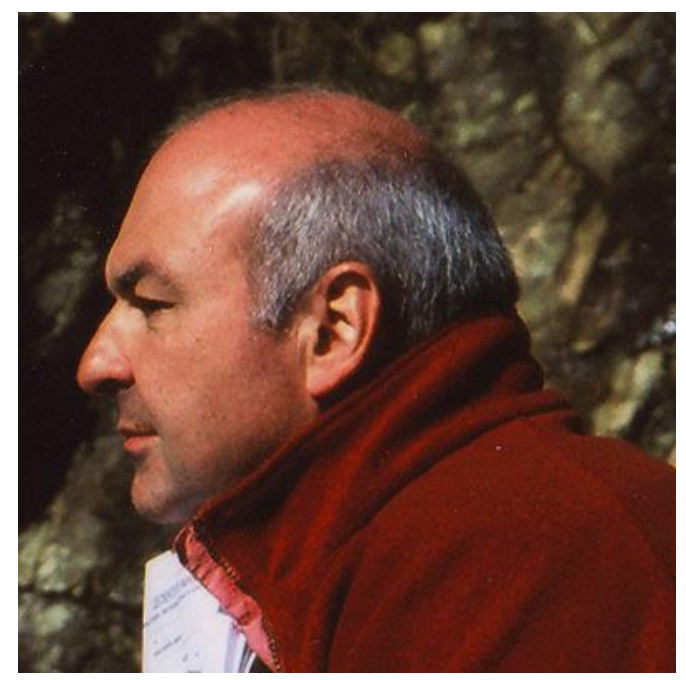

Francois Guilllocheau is currently professor of sedimentary geology at the University of Rennes 1 (Brittany, western France). He received his $\mathrm{PhD}$ in sedimentology from the Brest University (UBO) in 1983 and his National Doctoral Thesis (Doctorat d'Etat) in basin dynamics from the Strasbourg University (ULP) in 1990. He managed from 2008 to 2013 the «TopoAfrica» project funded by the French National Research Agency (ANR) dealing with the growth of the African topography - and their causes - since Jurassic times. His academic research focused on the relationships between mantle dynamics and erosion-sedimentation processes along large plateaus and plains and surrounding intracratonic and passive margins basins mainly in Africa and Western Europe. 


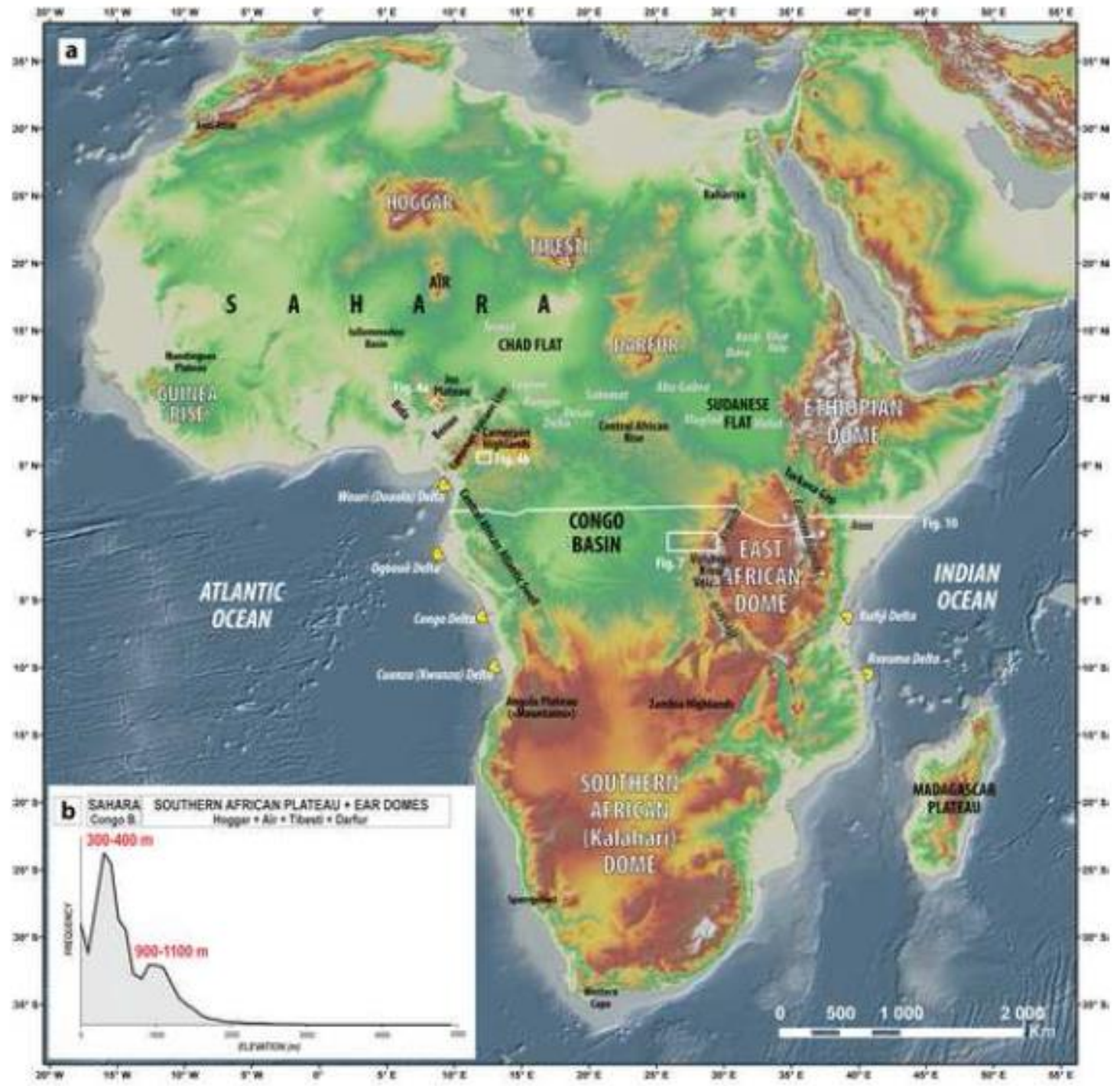

Figure 1 
a MANTLED ETCHPLAIN

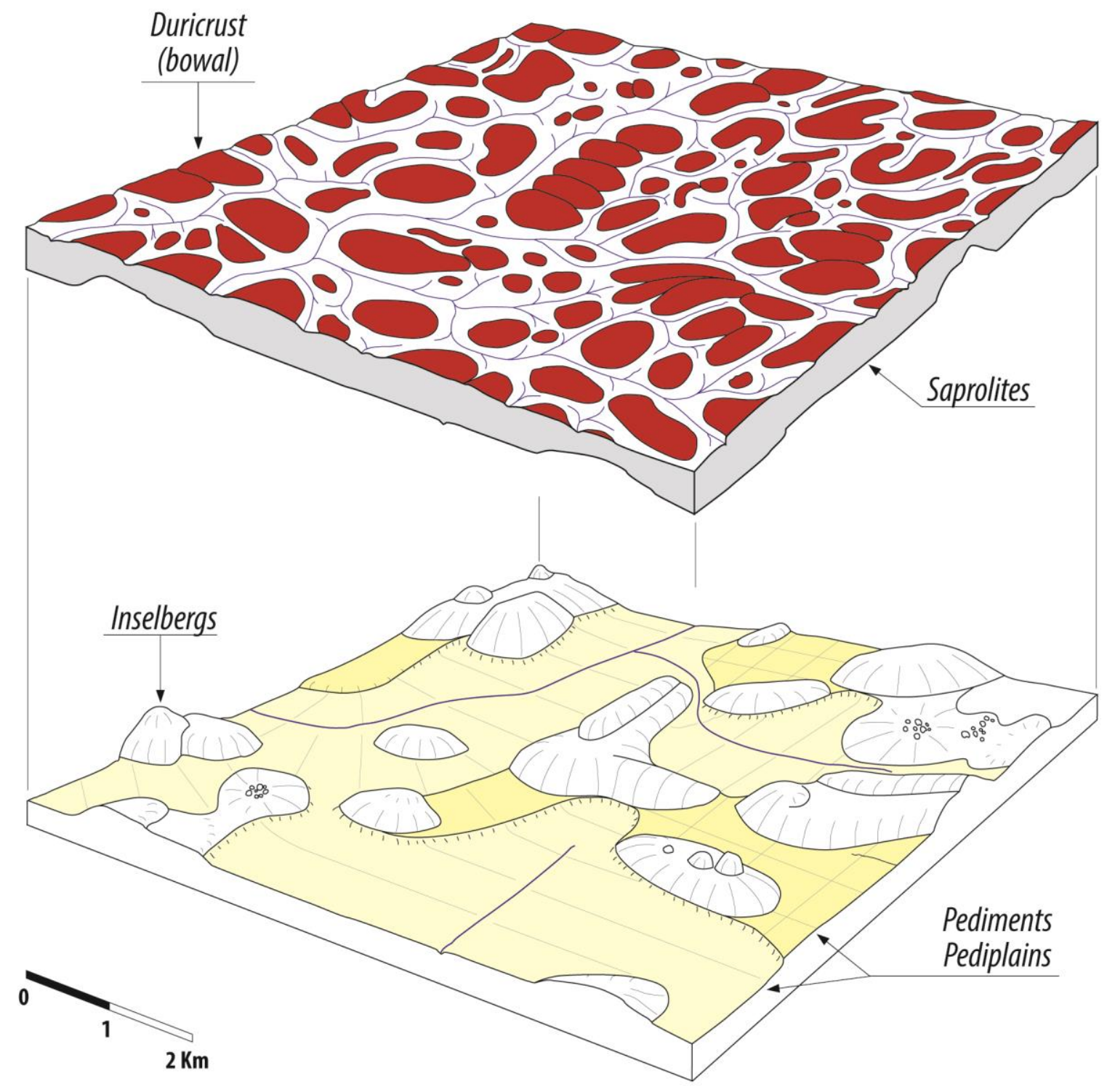

vertical exageration: $\mathbf{x} 10$

b STRIPPED ETCHPLAIN

Figure 2 


\section{a - DIFFERENT PEDIMENT PROFILES}

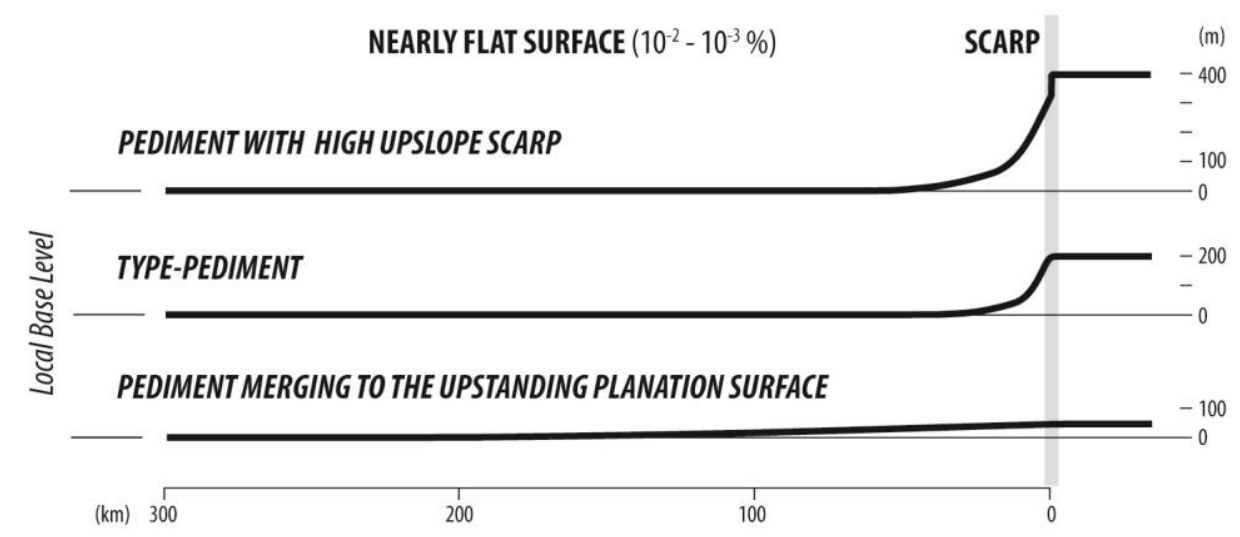

\section{b - PLAN VIEW OF THE SCARP GEOMETRY}

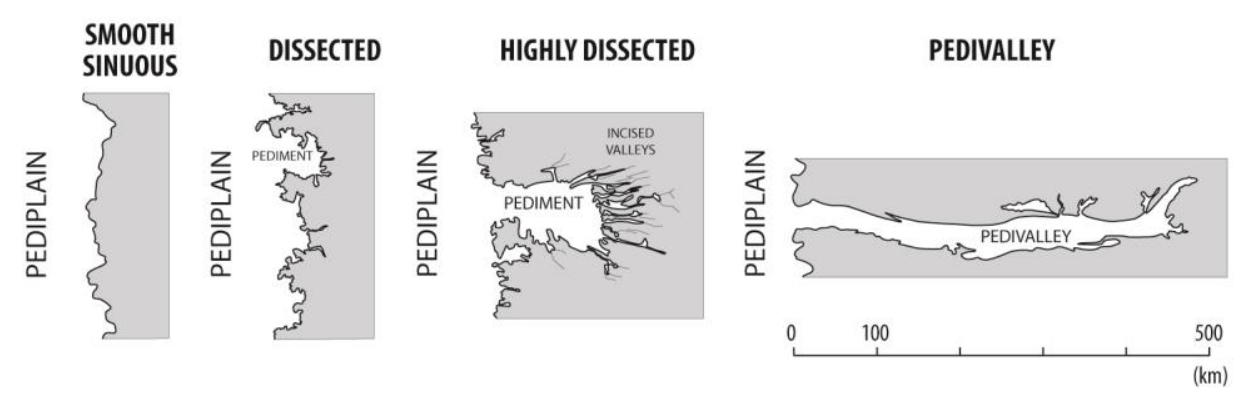

\section{c - PEDIMENT SYSTEM}

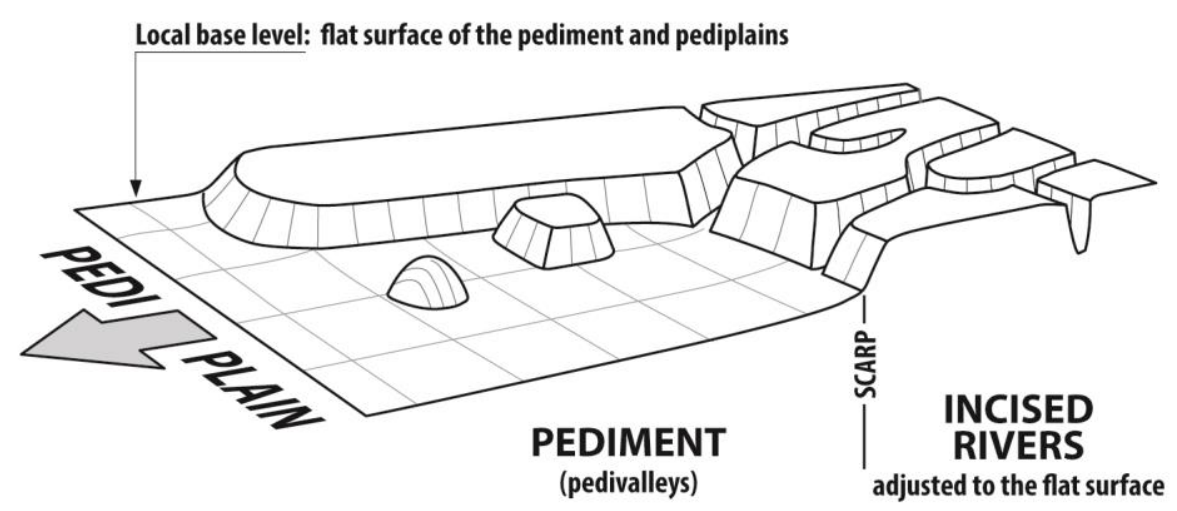

50-300m up to $500 \mathrm{~m}$ $\mathrm{x} 10 \mathrm{~km}$

Figure 3 
a JOS PLATEAU (Nigeria)
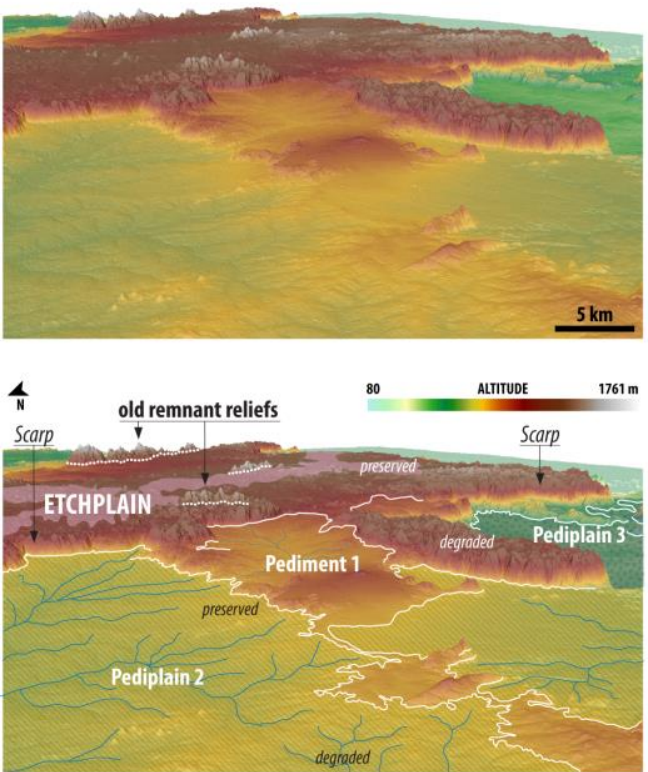

b CAMEROON HIGHLANDS

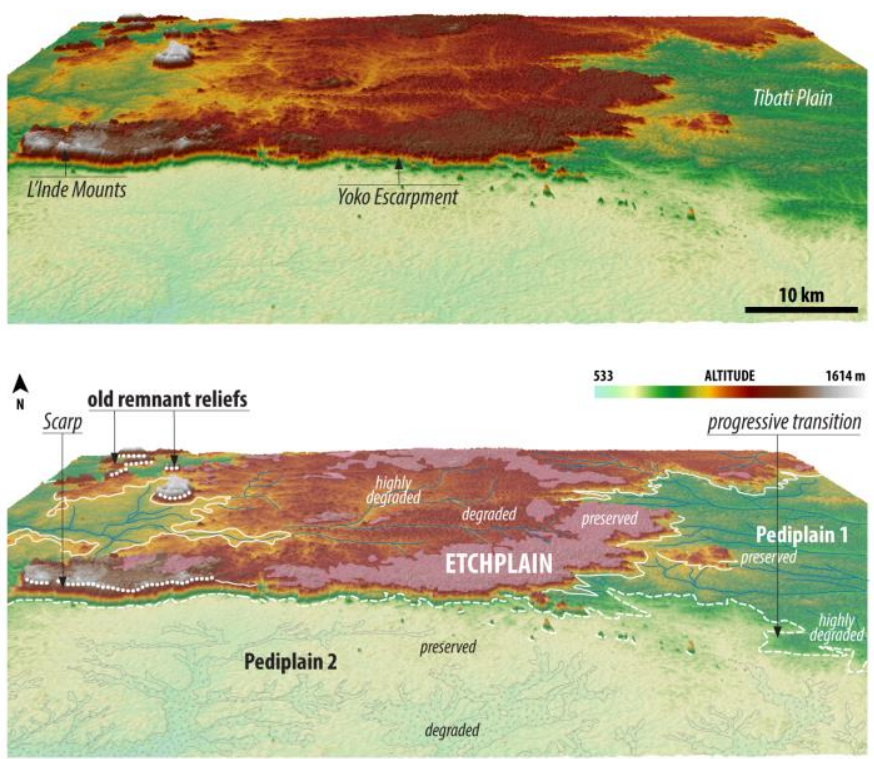

Figure 4 


\section{a AFRICAN PLATEAUS: STEPPED PLANATION SURFACES}

\begin{tabular}{|l|l|}
\hline- DEGRADATION \\
\hline
\end{tabular}

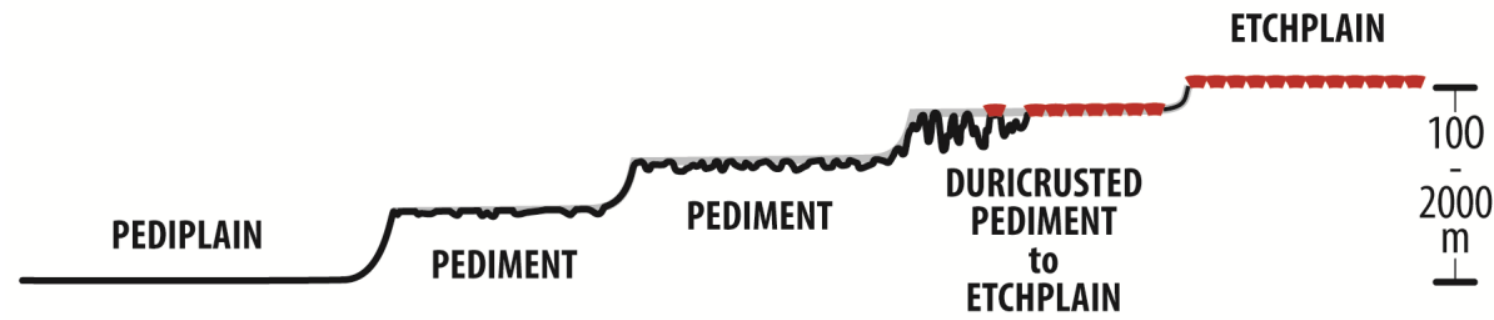

$\mid-10-1000 \mathrm{~km} \longrightarrow$

\section{b POSSIBLE PEDIMENTS EVOLUTION TROUGH TIME}

\section{SYNCHRONOUS SCARP RETREAT}

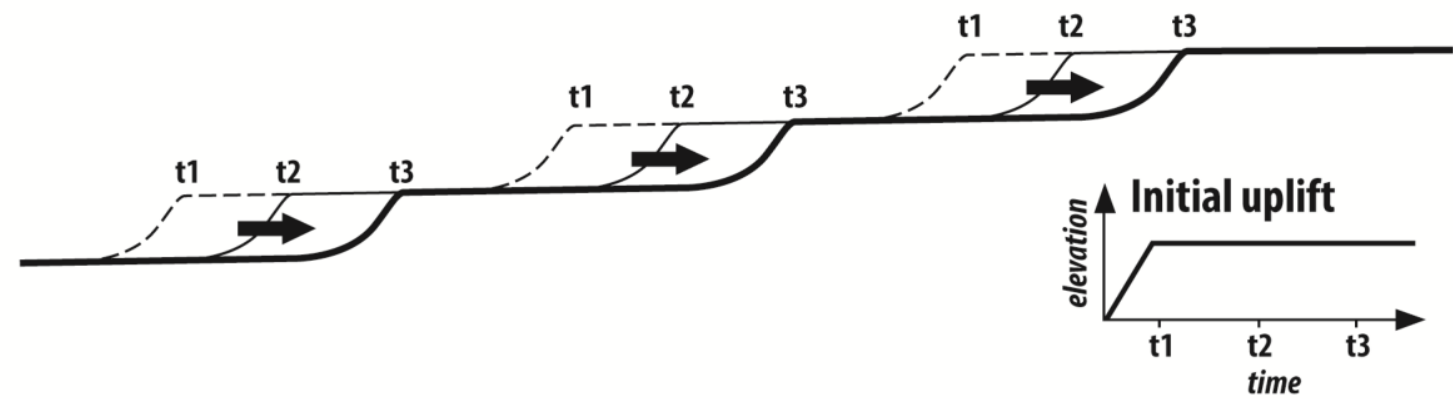

\section{SUCCESSIVE PEDIMENT FORMATION}
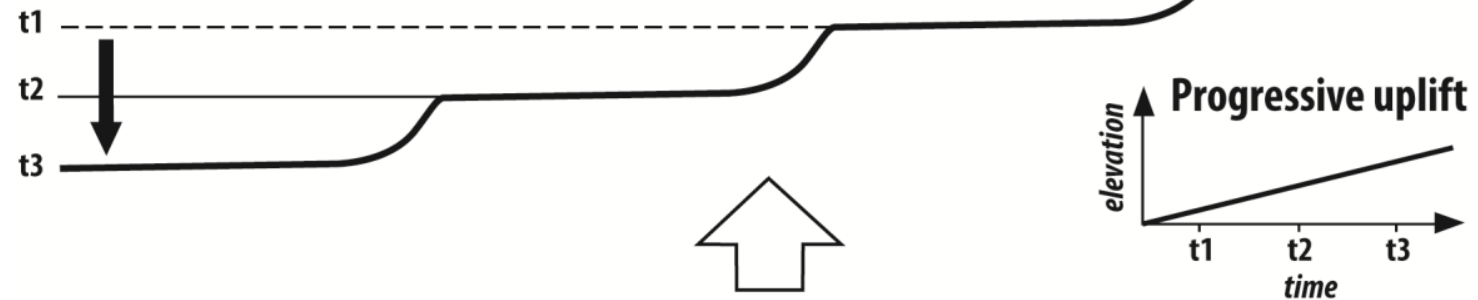

+ climate (precipitation) variations

Figure 5 


\section{a STEPPED PEDIMENTS AT TIME $\mathrm{t}$}

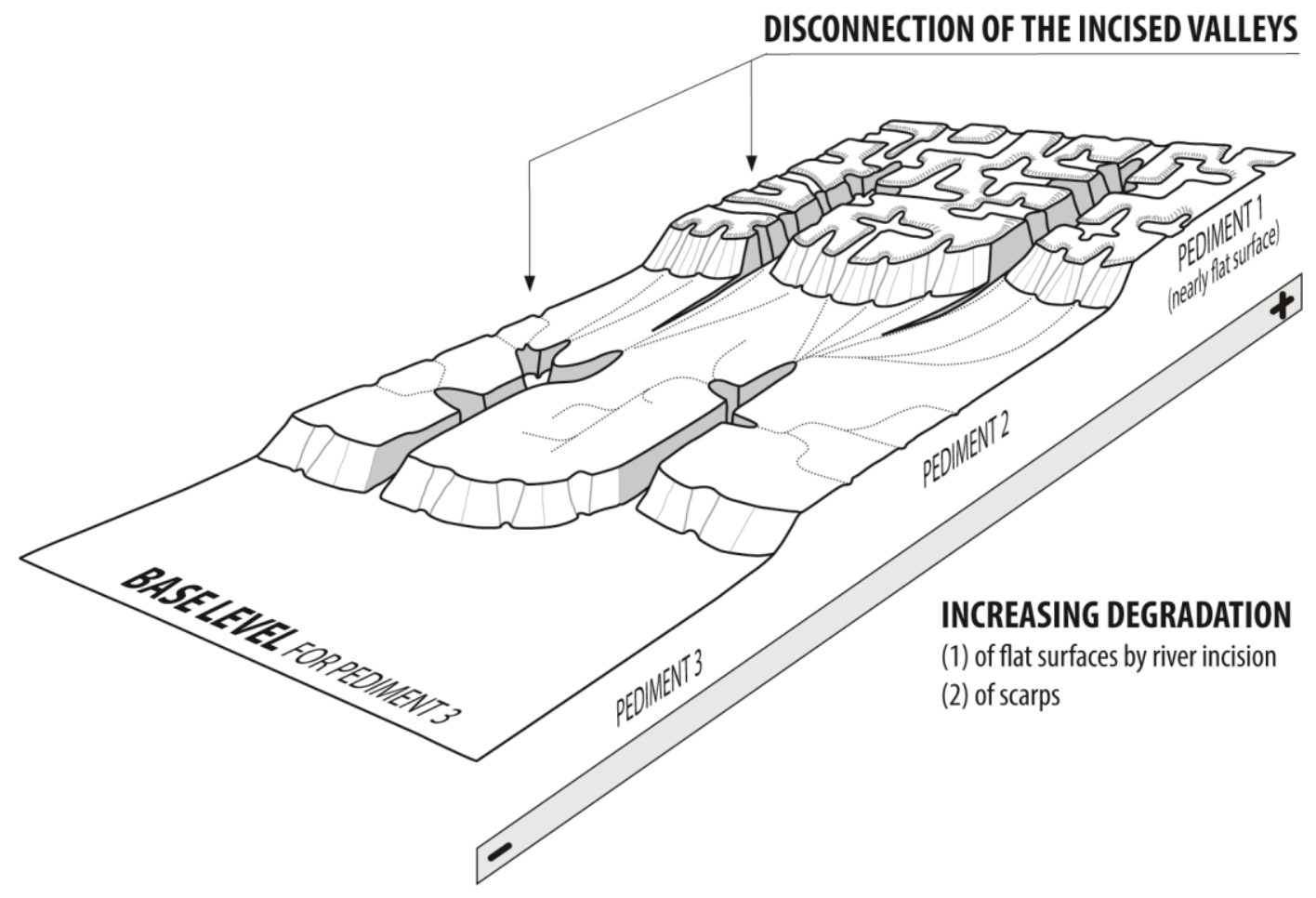

b PEDIMENTS RECONSTRUCTION AT TIME $t-n$ : before the incision of Pediment 3

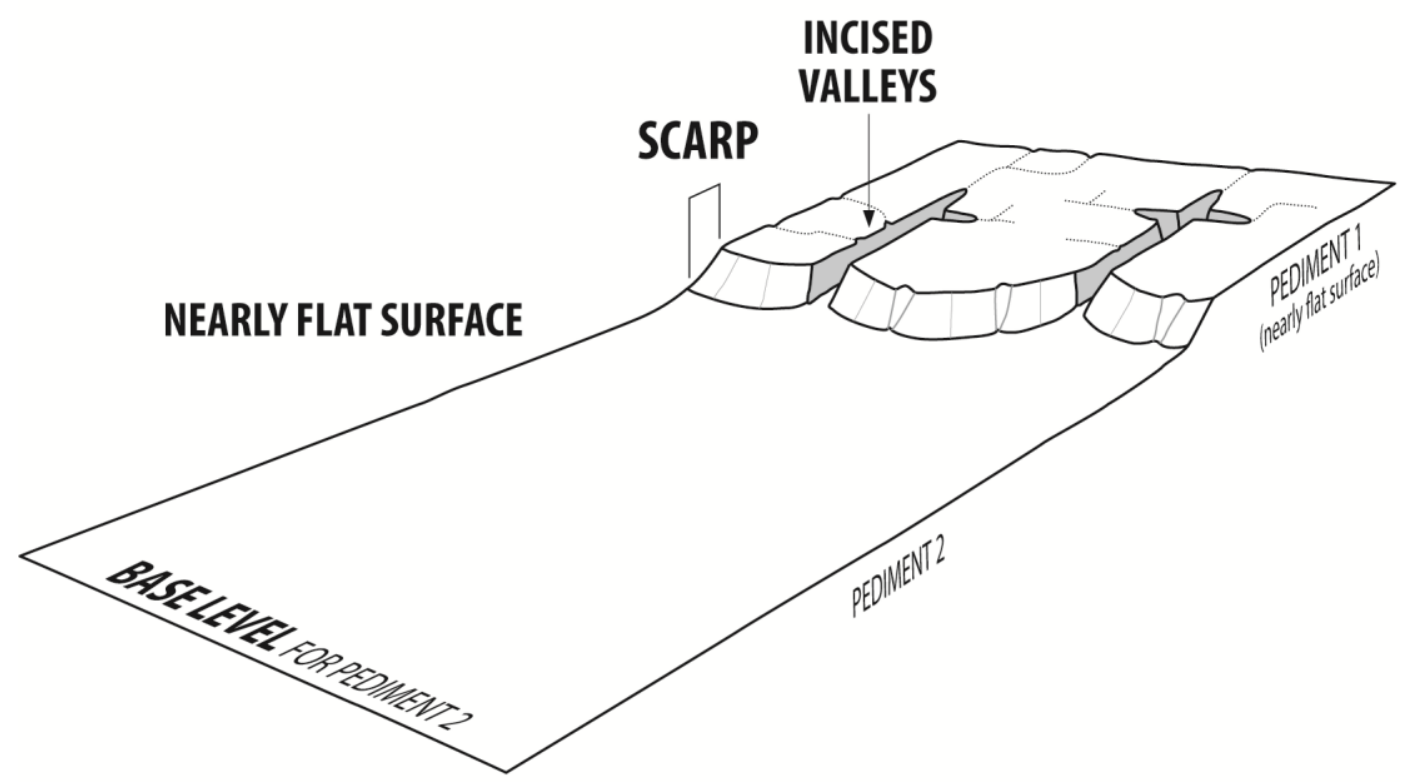

Figure 6 


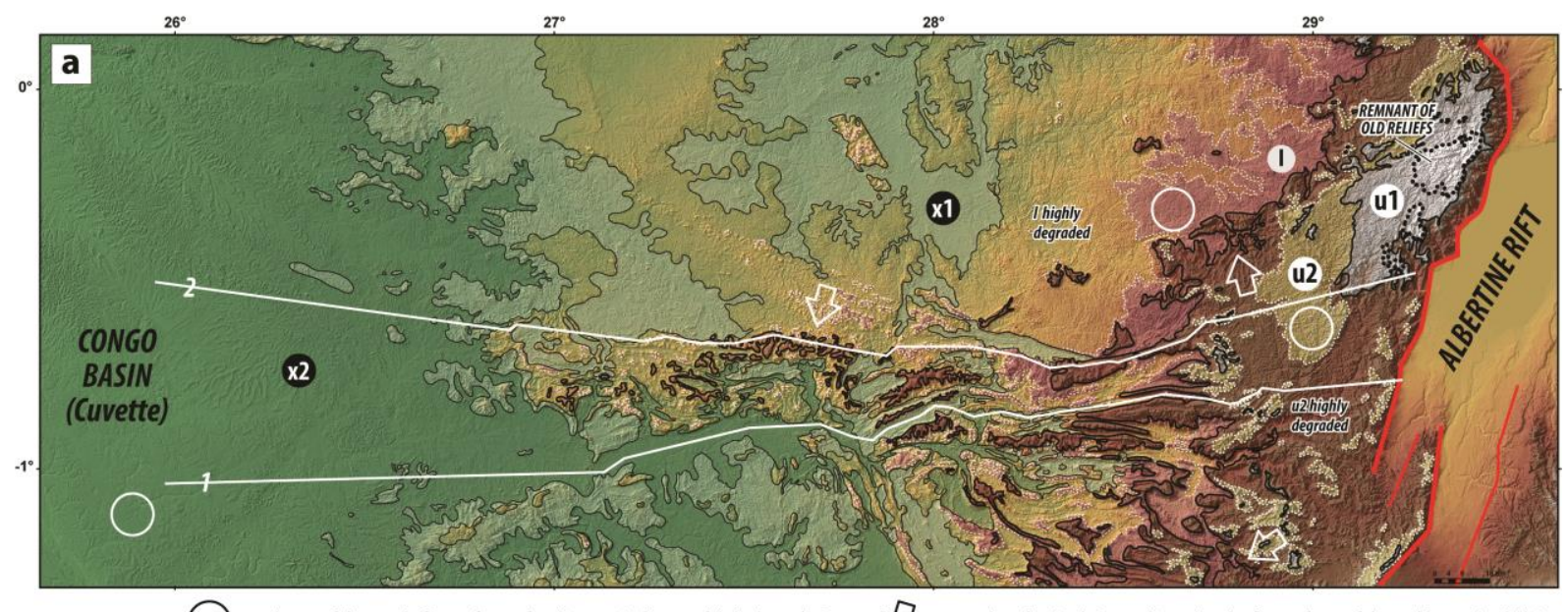

roughness of the nearly flat surfaces of pediments, indicator of their degradation $\sqrt{3}$ examples of incised rivers adjusted to the flat surfaces of the pediments/pediplains

b PROJECTED PROFILES 1 AND 2

$w$

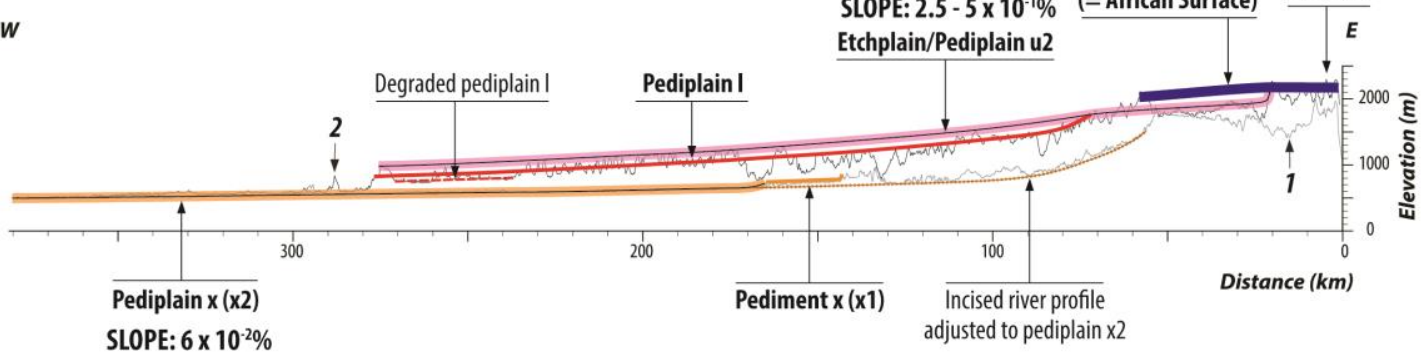

Figure 7 


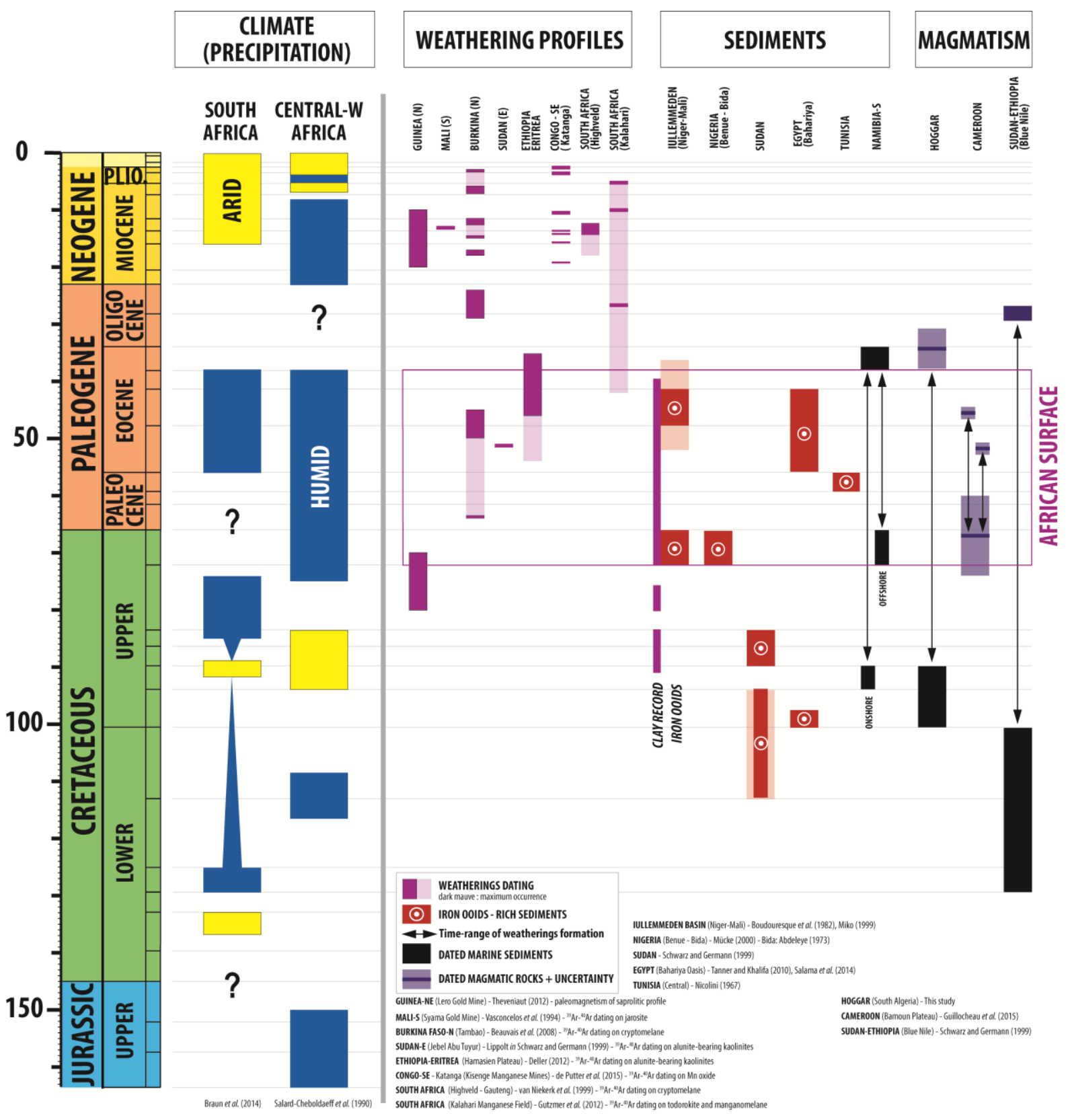

Figure 8 


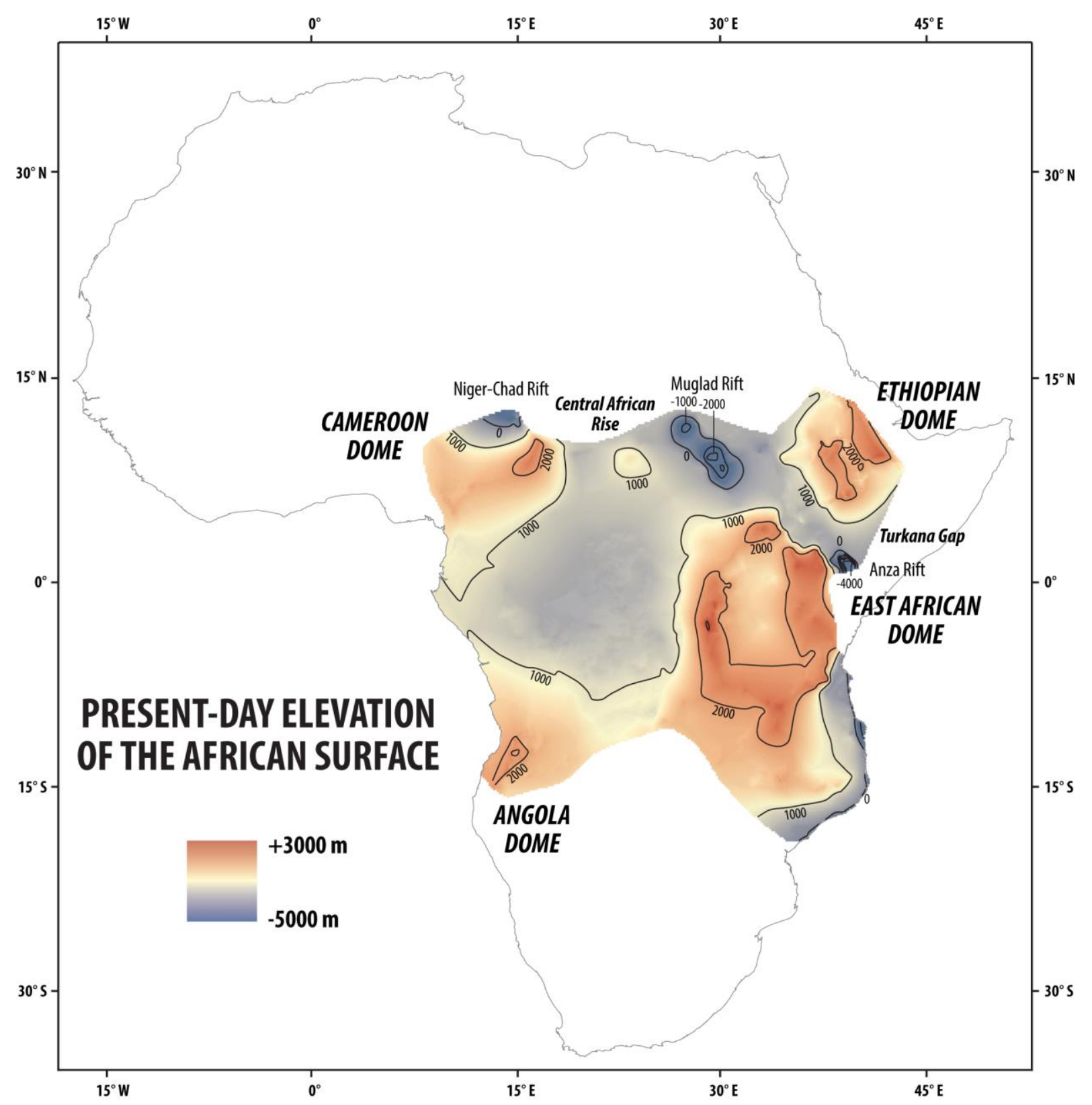

Figure 9 
w
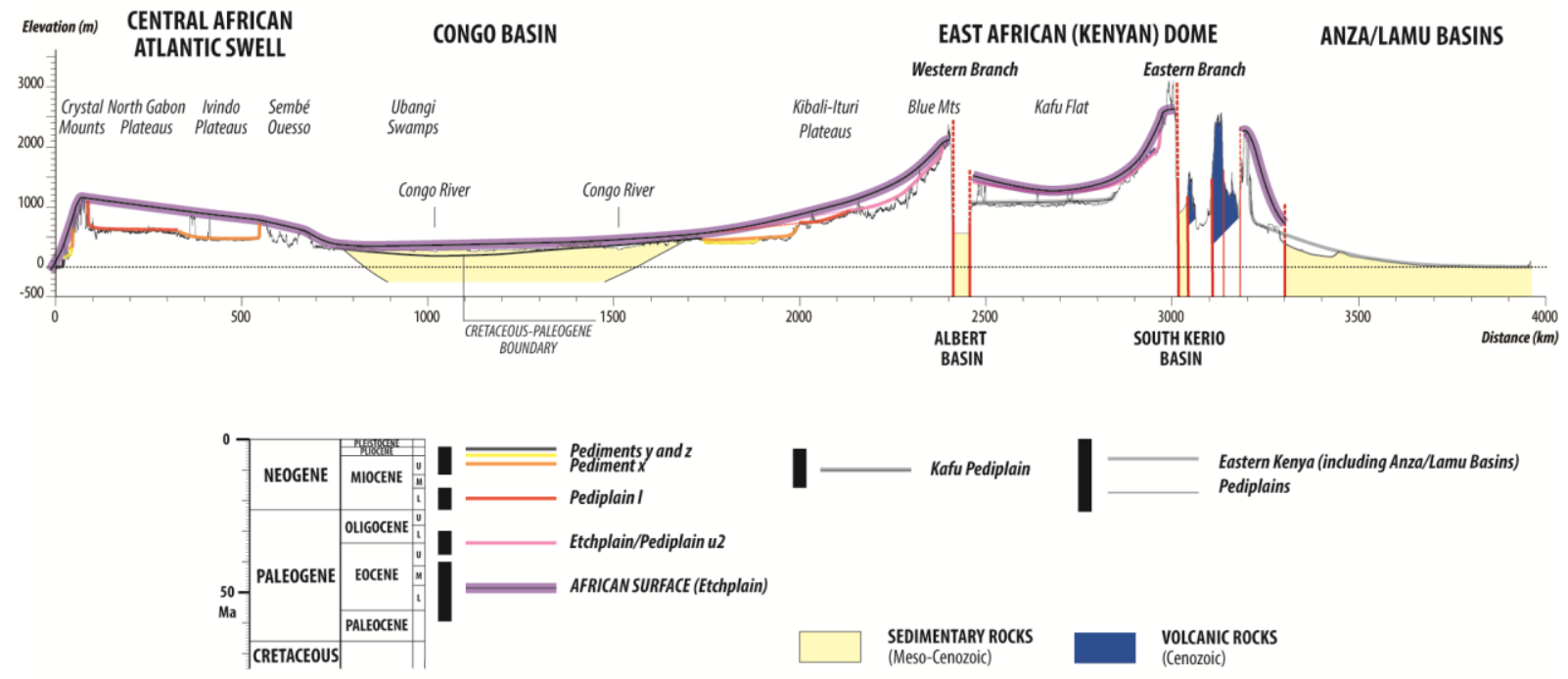

10-3 Ma (Uppermost Miocene-Lowermost Miocene) Pediment y-z

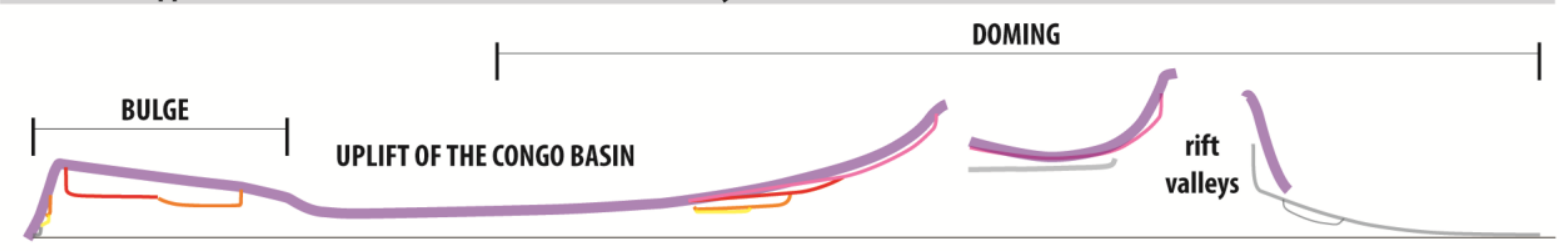

\section{1-6 Ma (Late Miocene) Pediment $x$}

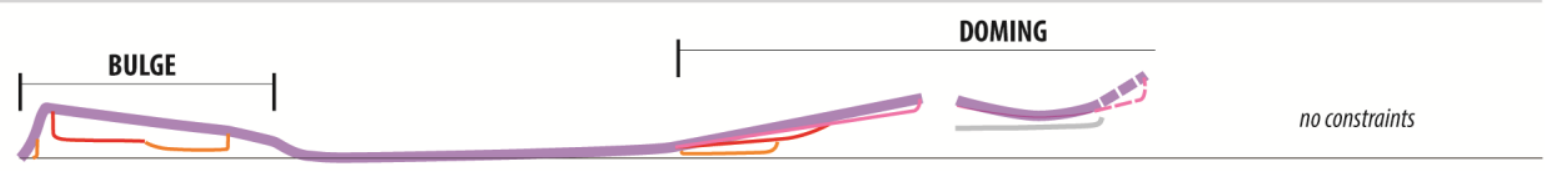

\section{0-16 Ma (Early Miocene) Pediplain I}

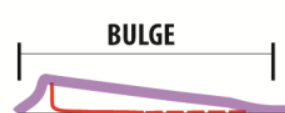

DOMING

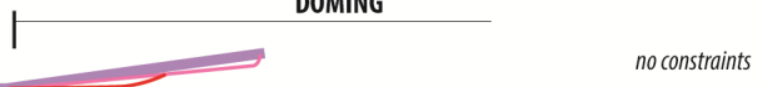

34 (38-30) Ma (Eocene-0ligocene boundary) Etchplain/Pediplain u2

DOMING

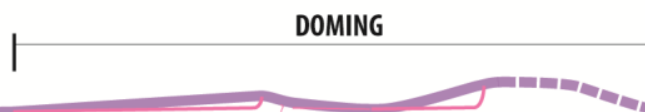

60-40 Ma (Late Paleocene-Late Eocene) AFRICAN SURFACE (Etchplain)

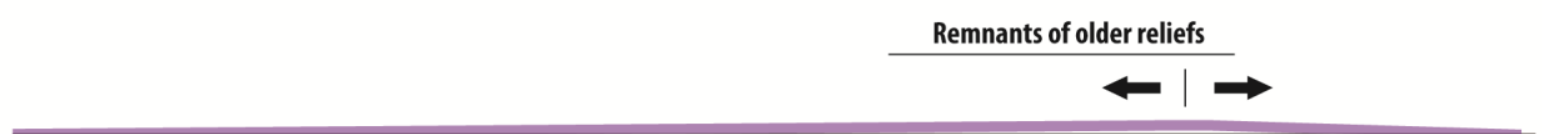

very low slope etchplain $\left(10^{-2}\right.$ to $\left.10^{-3} \%\right)$

DIVIDE

Figure 10 
60-40 Ma: AFRICAN SURFACE

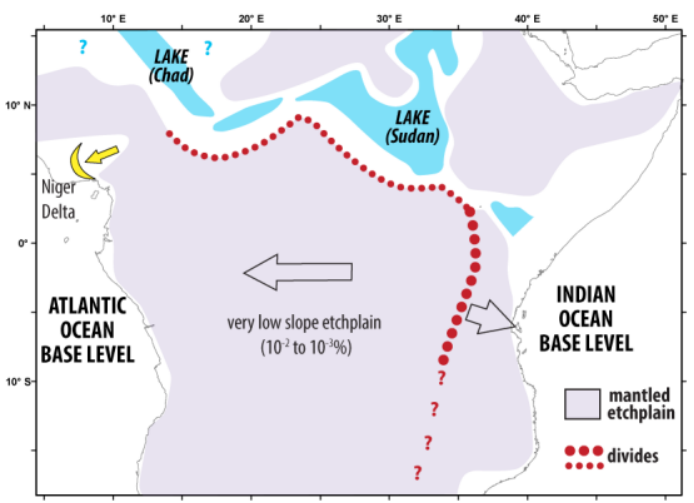

20-16 Ma: ATLANTIC BULGE

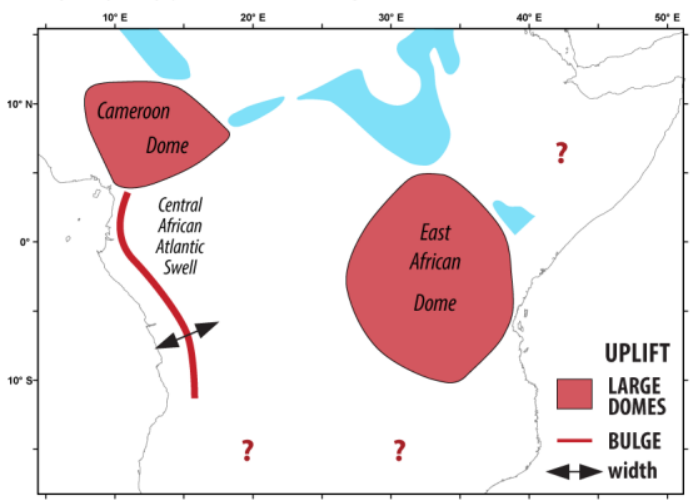

34 (38-30) Ma: FIRST DOMING
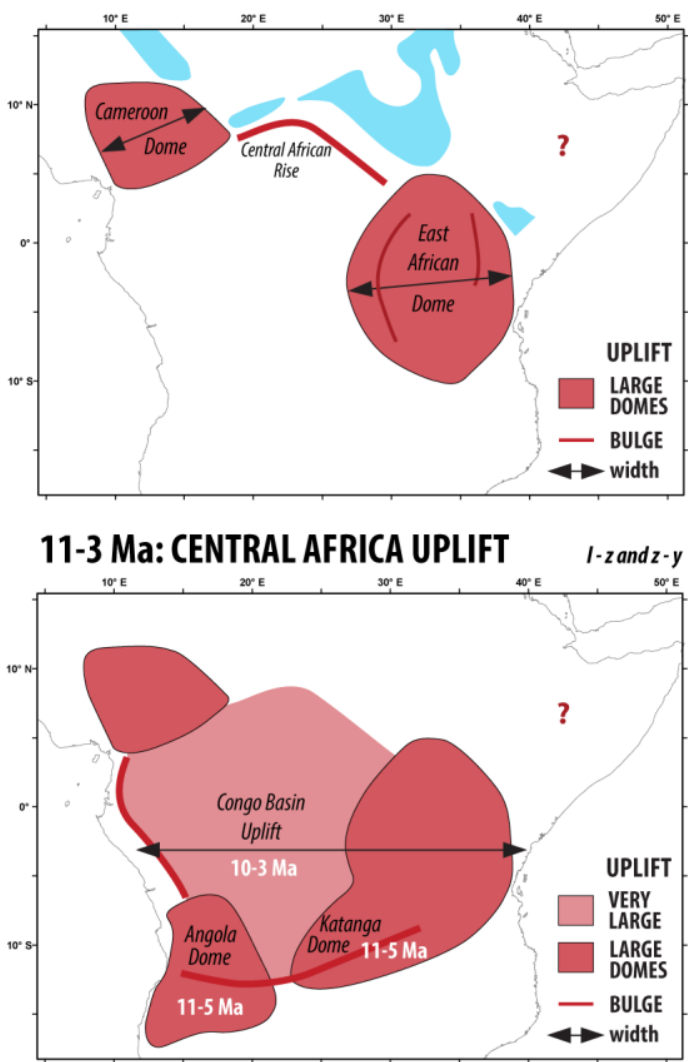

Figure 11 
Graphical abstract
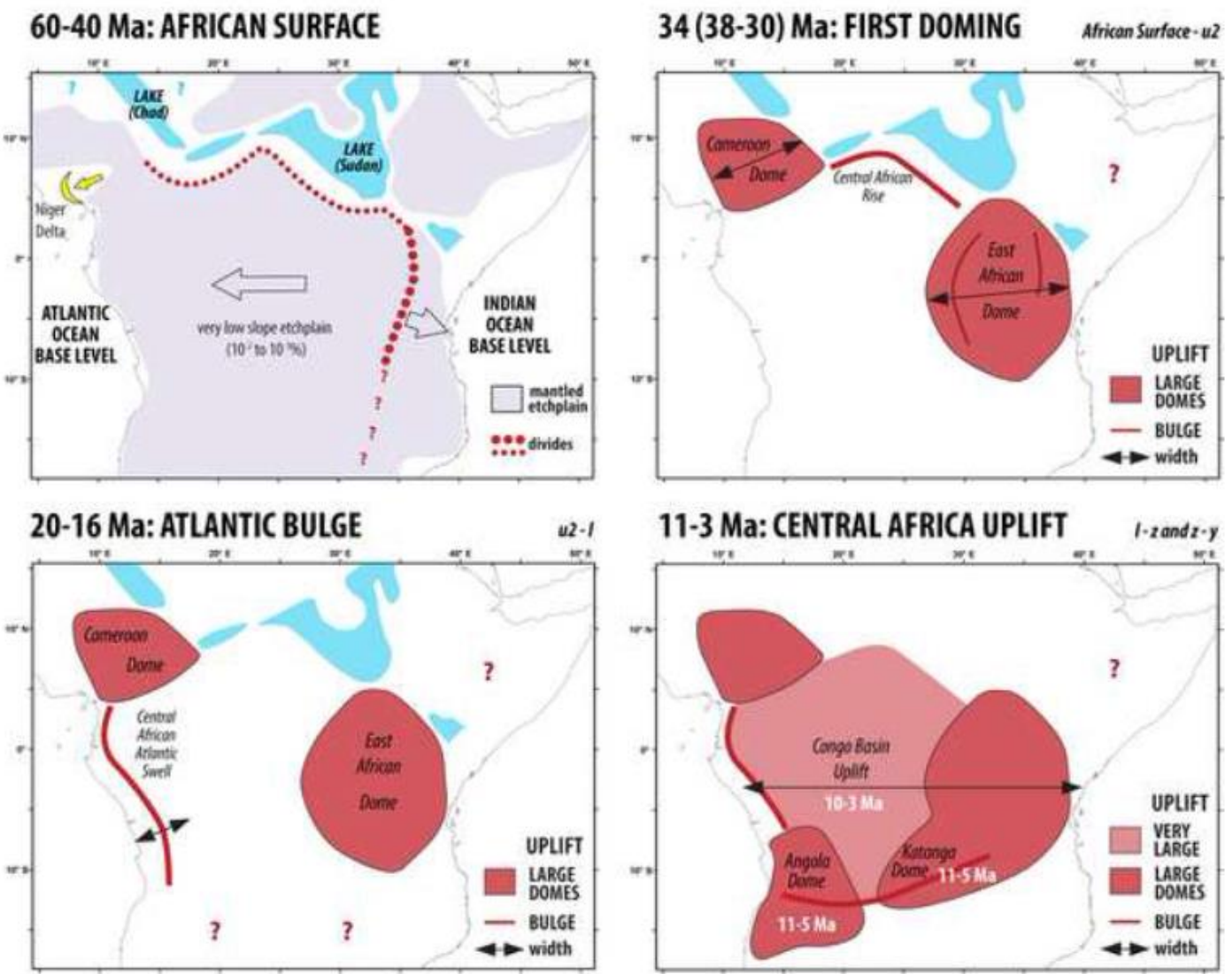


\section{RESEARCH HIGHLIGHTS}

- planation surfaces of Africa record very long wavelength deformation (several 1000 $\mathrm{km}$ )

- present-day topography of Central Africa is younger than 40-30 Ma

- very long wavelength deformation of Central Africa record changes in mantle dynamics 